\title{
La Porta Francigena: una encrucijada en el nacimiento del gran portal románico
}

\author{
Manuel CASTIÑEIRAS \\ Universitat Autònoma de Barcelona
}

\begin{abstract}
"El templo apostólico, que había empezado a labrarse antes de ascender Gelmírez a la sede, él lo ayudó a levantar del todo, él lo adorno generosamente. Cuando vuelto a la patria, presentes en la memoria las grandes obras de arte que había admirado al recorrer Francia, Italia y en especial Roma: ante los ojos las esplendideces del culto en el monasterio de Cluny, trató de realizar en Santiago algo de lo que había visto y presenciado, poniendo en todo ello al templo apostólico, al igual de los más notables del orbe católico."
\end{abstract}

Manuel Murguía, Don Diego Gelmírez $(1898)^{1}$

Los viajes de Diego Gelmírez (1070?-1140), primer arzobispo de Santiago, a la búsqueda de la mayor gloria para su sede, han sido el motivo de una reciente exposición itinerante, Compostela y Europa. La historia de Diego Gelmírez, celebrada en París (Musée des Monuments Français), en la Ciudad del Vaticano (Braccio di Carlomagno) y Santiago (Mosteiro de San Martiño Pinario), con motivo de la celebración del Año Santo Compostelano 2010. Más allá de su carácter conmemorativo, dicho proyecto, organizado por la $S$. A. de Xestión do Xacobeo de la Consellería de Cultura de la Xunta de Galicia y financiado con el apoyo de la Comisión Europea, ha querido subrayar su indudable vocación científica e investigadora a través de la publicación de un voluminoso libro $^{2}$, que cuenta con la participación de destacados especialistas en el tema, así como de un DVD que recoge los diversos materiales multimedia realizados para la muestra ${ }^{3}$. De ellos destaca, por su novedad, las reconstrucciones virtuales de la Porta Francigena (fig. 1) y del Altar Mayor

1 M. Murguía, Don Diego Gelmírez, Santiago de Compostela, 1991, p. 86 (1 $1^{\text {a }}$ ed. A Coruña, 1898).

2 Compostela y Europa. La historia de Diego Gelmírez, M. CAStiÑeIras (ed.), Santiago-Milán, 2010.

3 Compostela y Europa. La historia de Diego Gelmírez (DVD) contiene los vídeos -Los tiempos del obispo Diego Peláez y Los viajes de Diego Gelmírez- así como las reconstrucciones virtuales del Castillo de Torres de Oeste (Catoira, Pontevedra), de la Porta Francigena y del Altar Mayor de la Catedral de Santiago de Compostela. Para la justificación pormenorizada de los criterios seguidos en la recreación y estudio de estas dos últimas obras desaparecidas, véanse dos recientes trabajos: M. CASTIÑEIRAS y V. NoDAR, "Reconstruyendo la Porta Francigena de la Catedral de Santiago: materiales multimedia para una exposición de arte románico", Románico. Revista de arte de amigos del románico (AdR), 10 (2010), p. 83-95; "Para una reconstrucción del altar mayor de Gelmírez: cien años después de López Ferreiro", Compostellanum, 55, 2010, pp. 575-640; M. CASTIÑEIRAS, "El altar románico y su mobiliario litúrgico: frontales, vigas y baldaquinos", en Mobiliario y ajuar litúrgico en las iglesias románicas, P. L. Huerta (ed.), Aguilar de Campoo, 2011, pp. 11-75, espec. 11-44. 


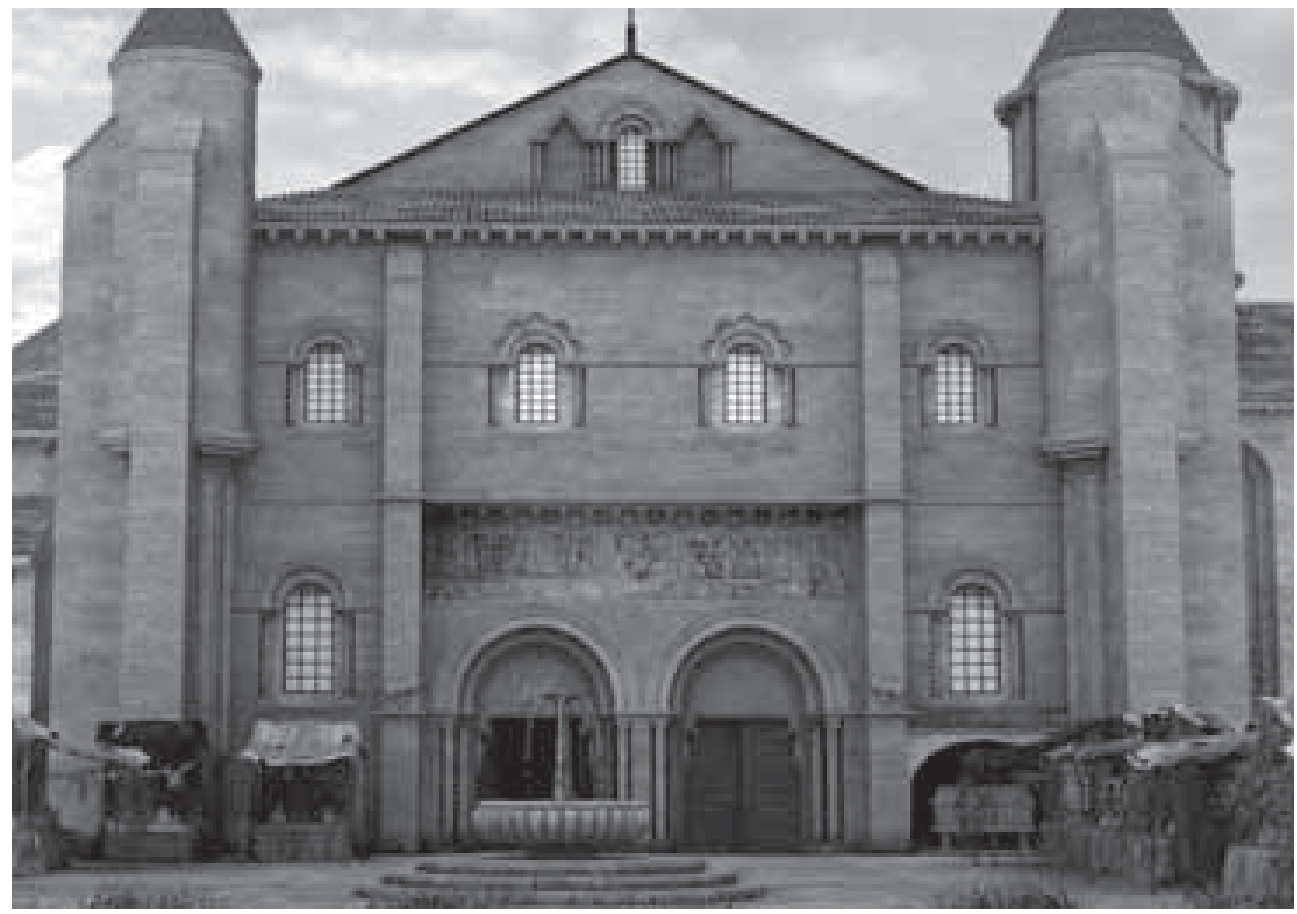

Fig. 1. Porta Francigena de la Catedral de Santiago (Reconstrucción hipotética en 3D). 2010. Asesor científico: Manuel Castiñeiras. Producción técnica: Tomas Guerrero-Magneto Studio (c) S.A. de Xestión do Plan Xacobeo. Santiago de Compostela.

de la Catedral de Santiago, realizadas por Tomás Guerrero-MagnetoStudio, bajo mi dirección científica. Con ellas se quería devolver al paisaje monumental del templo jacobeo el posible aspecto de dos obras desparecidas, llevadas a cabo durante el largo gobierno de Diego Gelmírez (1100-1140), que resultaban fundamentales para entender el papel de este personaje como patrón de las artes.

Dicha experiencia me ha permitido volver sobre la vieja cuestión del nacimiento del gran portal historiado románico, en el que las fachadas del transepto compostelano, realizadas entre 1101 y 1111 , parecen haber desempeñado un importante lugar, tanto por su precocidad como por la ambición de sus programas iconográficos. No obstante, dos hechos nos han impedido valorar hasta ahora, en buena medida, la contribución de los talleres activos en Santiago a inicios del siglo XII al desarrollo del portal historiado frente a otros ejemplos coetáneos, como los de Saint-Sernin de Toulouse, la Catedral de Módena o el polémico portal occidental de la abadía de Santa Fe de Conques. En primer lugar, como es bien sabido, de estas primitivas entradas gelmiríanas tan sólo ha llegado hasta nosotros la del lado sur, conocida como Puerta de Platerías, la cual presenta, sin embargo, un desagradable aspecto caótico fruto de algunos desajustes, en su concepción, entre traza arquitectónica y decoración, a los que hay que sumar una larga historia de asedios, restauraciones y 
remociones ${ }^{4}$. En segundo lugar, el hecho de que la primitiva puerta norte o Porta Francigena, que constituía el final del Camino Francés y la entrada por antonomasia de los peregrinos a la Catedral, fuese destruida en los años 1757 y 1758 para erigir la actual Puerta de la Azabachería, lo que nos privó para siempre del más genuino de los accesos gelmiríanos a la Catedral. No obstante, su aspecto original puede ser evocado a través de una serie de testimonios escritos, documentales y arqueológicos. A la célebre Guía del Códice Calixtino (V, 9) ${ }^{5}$-en la que se incluye una descripción del atrio o Paradisus, con su fuente, tiendas y fachada-, hay que añadir la numerosa serie de relieves que en su día fueron desmontados para ser reaprovechados en la Puerta de Platerías o bien fueron guardados en las dependencias catedralicias, para posteriormente pasar a formar parte de las colecciones del Museo de la Catedral.

\section{Una reconstrucción hipotética de la primitiva Porta Francigena}

Aunque Antonio López Ferreiro le dedicó un pionero apartado en el volumen tercero de su monumental historia de la Catedral de Santiago $(1900)^{6}$, debe reconocerse a Serafín Moralejo el primer estudio global del aspecto de la primitiva fachada norte de la Catedral de Santiago (1969), el cual era fruto de las investigaciones llevadas a cabo en su Tesis de Licenciatura ${ }^{7}$. No obstante, dicho autor nunca publicó un dibujo reconstructivo de la portada. Habría que esperar a 1996 para que en un cuaderno de la ASPG (Asociación Socio-Pedagóxica Galega), firmado por $\mathrm{M}^{\mathrm{a}}$ Pilar Camino Valdés Blanco, Faustino Seijas Seoane y Eduardo Álvarez González, se diese a conocer una primera propuesta de reconstrucción visual de la puerta norte ${ }^{8}$. Posteriormente, en el año 2003, el doctorando Victoriano Nodar realizó y publicó, a partir de un esquema proporcionado por mí, un dibujo, que

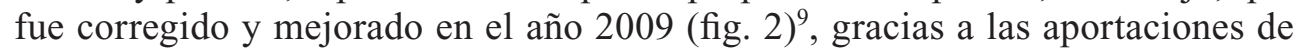

4 He preferido prescindir en el presente artículo de un análisis minucioso de la Puerta de Platerías, a la cual le he dedicado recientemente un extenso estudio en mi trabajo "Las portadas del crucero de la Catedral de Santiago (1101-1111)", en Alfonso VI y su legado, Congreso Internacional, Sahagún (León), 29-31 octubre 2009, León, 2011, pp.63-86.

5 Liber sancti Iacobi. Codex Calixtinus, V, 9, trad. A. Moralejo, C. Torres y J. Feo, Santiago de Compostela, 1999, pp. 557-558 ("De la fuente de Santiago"), 558 ("Del Paraíso de la Ciudad”), 559-560 ("De la Puerta Septentrional”) (1 ${ }^{\mathrm{a}}$ ed. Santiago, 1951). A partir de ahora citado como CC.

6 A. López Ferreiro, Historia de la Santa A. M. Iglesia de Santiago de Compostela, III, Santiago, 1900, pp. 115-121.

7 S. Moralejo, "La Primitiva Fachada Norte de la Catedral de Santiago", Compostellanum, XIV, 3-4, (1969), pp. 623-668.

8 Map. Camino Valdés Blanco, F. Seijas Seonne, E. Álvarez González, Arte románica. Arquitectura y escultura da catedral de Santiago, Vigo, 1996, pp. 44-45 (acuarela firmada por F. Seijas).

9 S. Fernández Pérez y V. NodAr, "Un proyecto de reconstrucción hipotética de las portadas del transepto de la Catedral de Santiago en época de Diego Gelmírez”, Compostellanum, XLVIII, 1-4 (2003), pp. 605-613, esp. fig. 1; M. CAstiñEIRAs, "La Catedral de Santiago de Compostela (1075-1122): obra maestra del románico europeo", Las maravillas del románico español, dir. Pedro Luis Huerta, Aguilar de Campoo, 


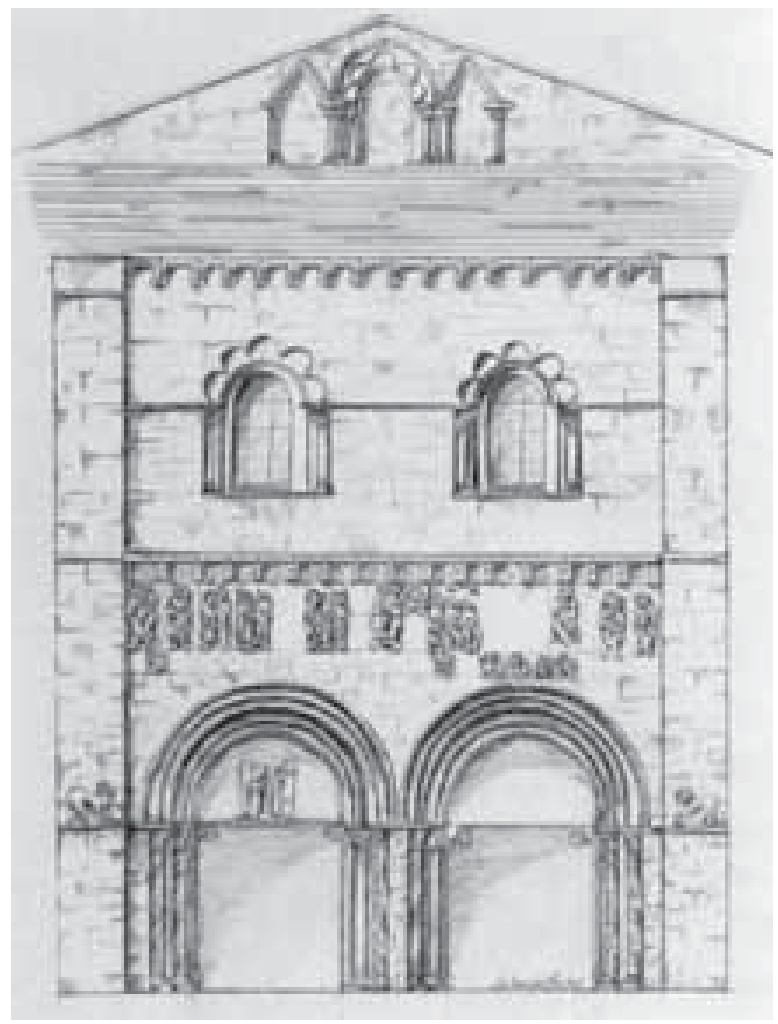

Fig. 2. Reconstrucción hipotética de la puerta norte (dibujo: Victoriano Nodar). un plano de Simón Rodríguez de 1739, conservado en el Archivo de la Catedral de Santiago y estudiado brillantemente por Alberto Fernández ${ }^{10}$. Paralelamente, John Williams realizó en el año 2008 su propia reconstrucción, a mi entender, poco afortunada ${ }^{11}$. Por ello, con motivo de la exposición itinerante Compostela y Europa. La historia de Diego Gelmírez, se elaboró, por primera vez, una reconstrucción hipotética en 3D del primitivo aspecto de este acceso norte de la Catedral (fig.1), no sólo de la portada sino también de la plaza adyacente. De este modo, en un lenguaje accesible al espectador contemporáneo, inmerso en la sociedad de la imagen y de la comunicación audiovisual, se presentaba un producto audiovisual fruto de la investigación históricoartística más puntera y que, a falta de una excavación arqueológica sistemática de la zona, representaba una paso de gigante en el conocimiento del monumento románico.

En la elaboración de dicha propuesta, hubo que plantearse una serie de cuestiones con el objeto de estructurar el espacio en el que se alzaba la primitiva fachada. Todas ellas fueron contrastadas tanto con la descripción del Códice Calixtino (V, 9) como con

2009, pp. 229-289, esp. p. 252, fig. 15; Idem, “Didacus Gelmirius, patrono de las artes. El largo camino de Compostela: de periferia a centro del Románico”, Compostela y Europa. La historia de Diego Gelmírez, M. Castiñeiras, (ed.) Santiago-Milán, 2010, pp. 32-97, esp. p. 64.

10 A. Fernández GonzÁlez, "Un viejo plano olvidado en el Archivo de la Catedral de Santiago: la Porta Francigena, su atrio y la Corticela en el año 1739”, Compostellanum, XLVIII, 1-4, (2003), pp. 701-742, esp. fig. 1-2, 9 .

11 J. Williams, "Framing Santiago", Romanesque Art and Thought in the Twelfth Century. Essays in Honor of Walter Cahn, C. Hourihane (ed.), Index of Christian Art, Princeton University-Penn State University Press, 2008, pp. 219-238, esp. p. 232. 
la comparación con monumentos u obras de arte coetáneas ${ }^{12}$. En primer lugar, con respecto a la articulación del atrio o Paradisus que se extendía ante la fachada, se decidió la colocación perpendicular de los nueve escalones que daban a la plaza, cuyo nivel era similar al del atrio actual ${ }^{13}$, así como el aspecto de la célebre fuente dedicada por el Tesorero Bernardo en 1122 (fig. 3), en la que se corrige, en parte, el dibujo reconstructivo

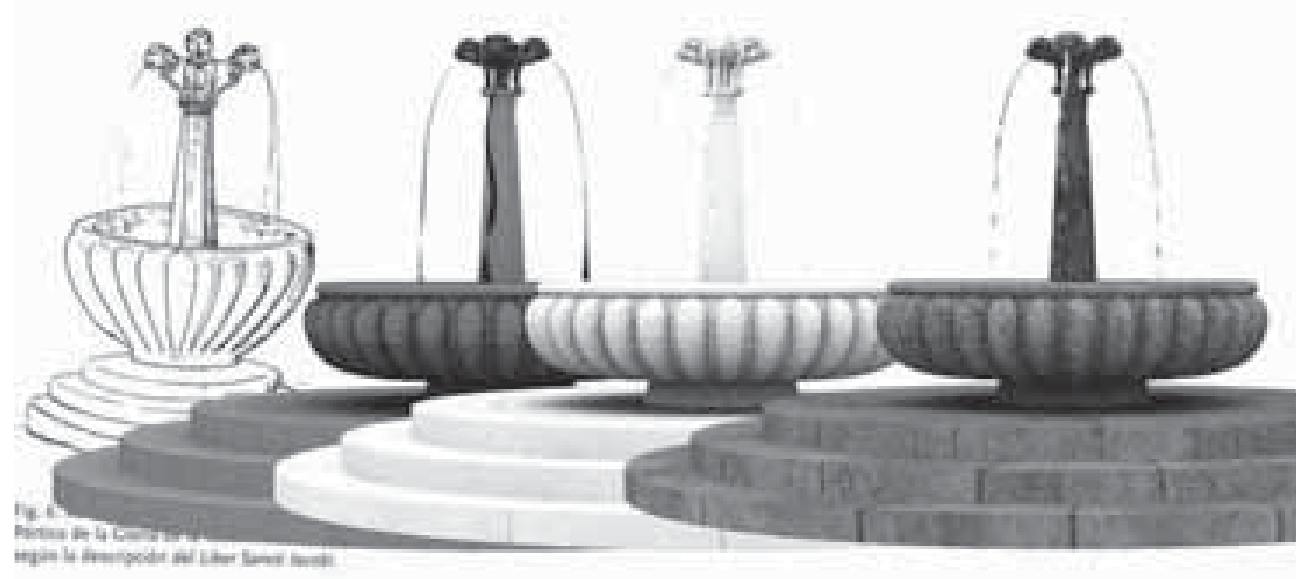

Fig. 3. Proceso de reconstrucción 3D de la fuente del Paradisus. Autor: Tomás Guerrero-Magneto Studio.

de ésta realizado por Moralejo en $1983^{14}$. En segundo lugar, para el alzado del edificio, con sus cubiertas, torres y fachada, se partió del aspecto de Platerías (fig. 4) teniendo en cuenta las diferencias existentes entre ambas con respecto a la cota en el terreno, pues al estar la plaza norte más elevada su fachada era de menor altura. El frontis estaba enmarcado por dos torrecillas laterales de estilo poitevino, las cubiertas del edificio eran de tejas de barro cocida, como las encontradas en la restauración de las cubiertas de la catedral en los años $80^{15}$, y en la calle lateral derecha se situaba un arcosolio que cobijaría el sepulcro de Raimundo de Borgoña, cuyas trazas todavía se conservan en la actual sacristía de Santa Catalina y que sería una evocación del panteón de la Porte des Comtes de Saint-Sernin de Toulouse (fig. 5) ${ }^{16}$.

12 Para una minuciosa formulación de los criterios seguidos en la reconstrucción de la Porta Francigena, remito en todo este apartado a M. CastiñEIRAs y V. Nodar, "Reconstruyendo la Porta Francigena de la Catedral de Santiago", véase nota 3.

13 A. Vigo Trasancos, La Catedral de Santiago y la Ilustración. Proyecto clásico y memoria histórica (1757-1808), Madrid, 1999, p. 84.

14 S. Moralejo, "La imagen arquitectónica de la Catedral de Santiago", Il Pellegrinaggio a Santiago e la letteratura jacopea. Atti del Convegno Internazionale di Studi, Perugia, 1983, G. Scalia (ed.), Perugia, Università degli Studi di Perugia, 1985, pp. 37-61, fig.6.

15 S. Moralejo, "The Codex Calixtinus as an Art-Historical Source", The Codex Calixtinus and the Shrine of St. James, J. Williams, A. Stones (eds.), Tübingen, 1992, pp. 207-226, esp. pp. 215-216, p. 225, fig. 4.

16 S. Moralejo, “¿Raimundo de Borgoña (+1071) o Fernando Alfonso $(+1214)$ ?, Un episodio olvidado en la historia del Panteón Real compostelano", Galicia en la Edad Media, Actas del Coloquio de Santiago de 


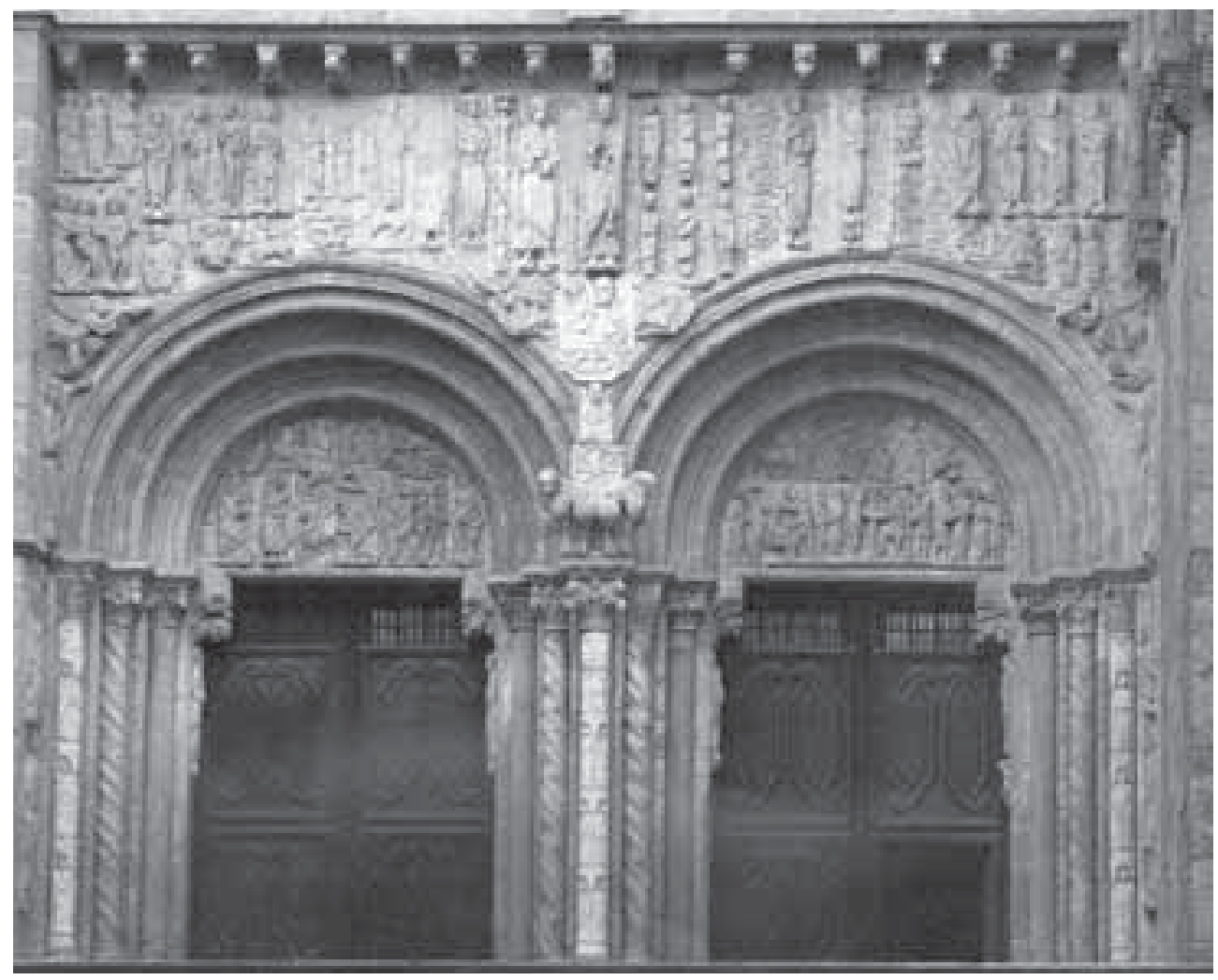

Fig. 4. Catedral de Santiago, brazo sur del transepto, fachada de Platerías, 1103-1111.

En tercer lugar, con respecto al friso, a pesar de la menor altura de la fachada norte, al mantenerse las líneas de imposta generales de la catedral, éste gozaba de la misma anchura y altura que el de Platerías, por lo que su aspecto, más cercano al espectador, debido a la menor elevación de las puertas, debía de ser conmovedor. Según la descripción del Calixtino (V, 9), éste se encontraba profusamente decorado con relieves escultóricos, de los cuales hemos conservado una buena parte, ya que tras la destrucción de la fachada un grupo de lastras fue reutilizado en el frontispicio, jambas y contrafuertes de Platerías, mientras que otra serie de piezas fueron guardadas, e incluso reutilizadas como decoración, en las dependencias ca-

Compostela, 1987, Madrid, 1990 (reed. Patrimonio artístico de Galicia y otros estudios: Homenaje al profesor Dr. Serafín Moralejo Álvarez, A. Franco Mata (ed.), Santiago de Compostela, 2004, II, pp. 173-182, esp. p. 174); J. A. Puente Míguez, «El sepulcro del Conde don Raimundo de Borgoña en la catedral de Santiago», en Estudios sobre patrimonio artístico. Homenaje del departamento de Historia del Arte y de la Facultad de Geografia e Historia de la Universidad de Santiago de Compostela a la Prof. Dra. Ma del Socorro Ortega Romero, Santiago de Compostela: 2002, pp. 83-95. 


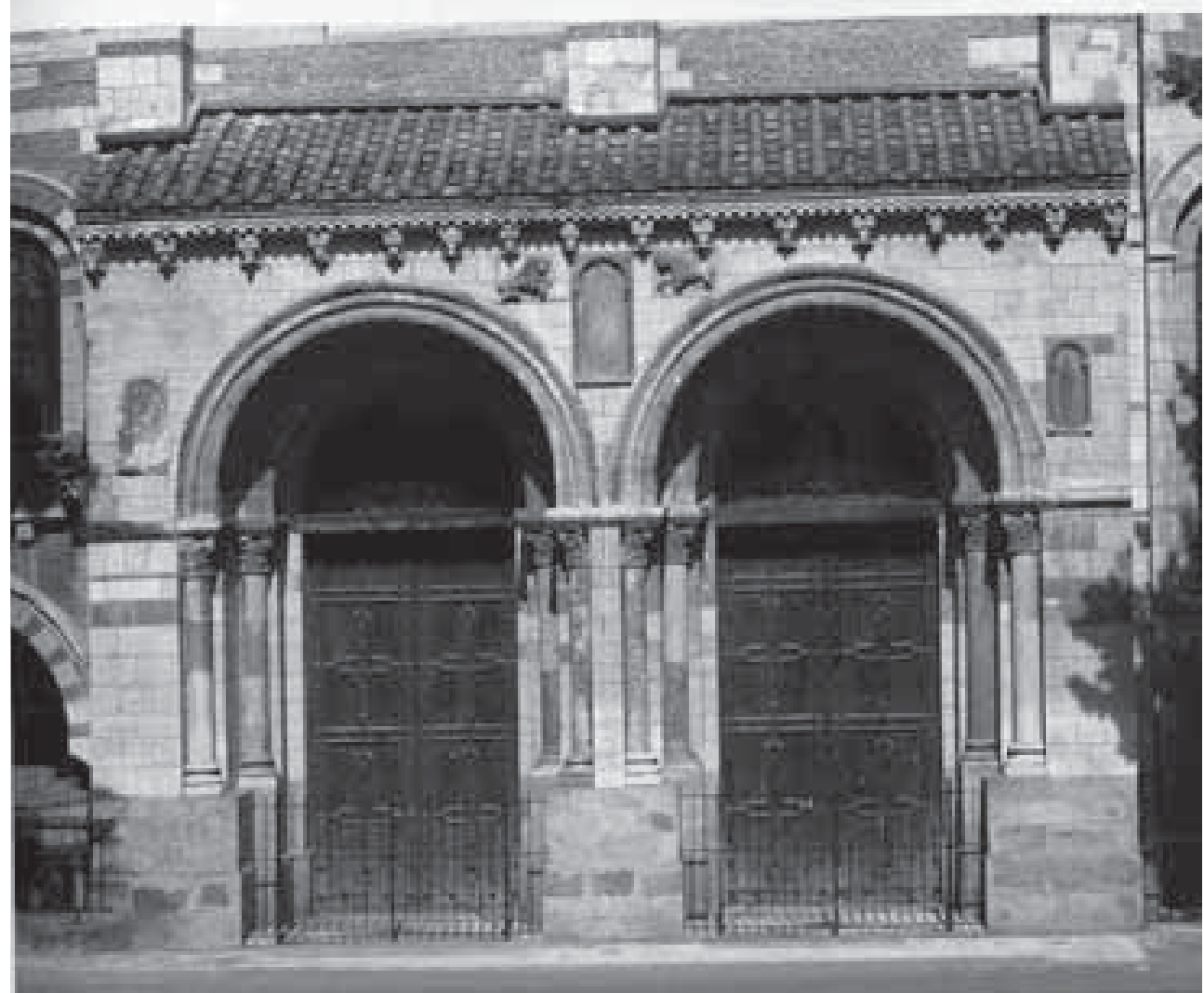

Fig. 5. Basílica de Saint-Sernin de Toulouse, brazo sur del transepto: Porte des Comtes, 1080-1090.

tedralicias, formando hoy parte de los fondos del Museo de la Catedral. Aunque la propuesta de reconstrucción (fig. 6) quiso seguir, en este capítulo, las hipótesis de Moralejo, se tuvieron que resolver algunos problemas fundamentales. Así, en primer lugar, para la composición general hubo de recurrirse a la comparación con el frontispicio de la puerta norte de San Quirce de Burgos (1125-1150) (fig. 7), obra menor que seguramente es un reflejo de la primitiva puerta norte compostelana ${ }^{17}$. En segundo lugar, en lo que respecta a relieves no conservados que formaban parte de ciclos narrativos, como el Génesis o el Calendario, se echó mano de ciclos contemporáneos similares.

La parte superior del frontispicio estaba decorado con un friso del Génesis, cuya narración se dividía en dos partes en torno a un Pantocrator rodeado por el Tetramorfos, de cuyo grupo se conservan solamente dos lastras reutilizadas en Pla-

17 M. CAstiñeIras, "La catedral de Santiago", "Didacus Gelmirius". 


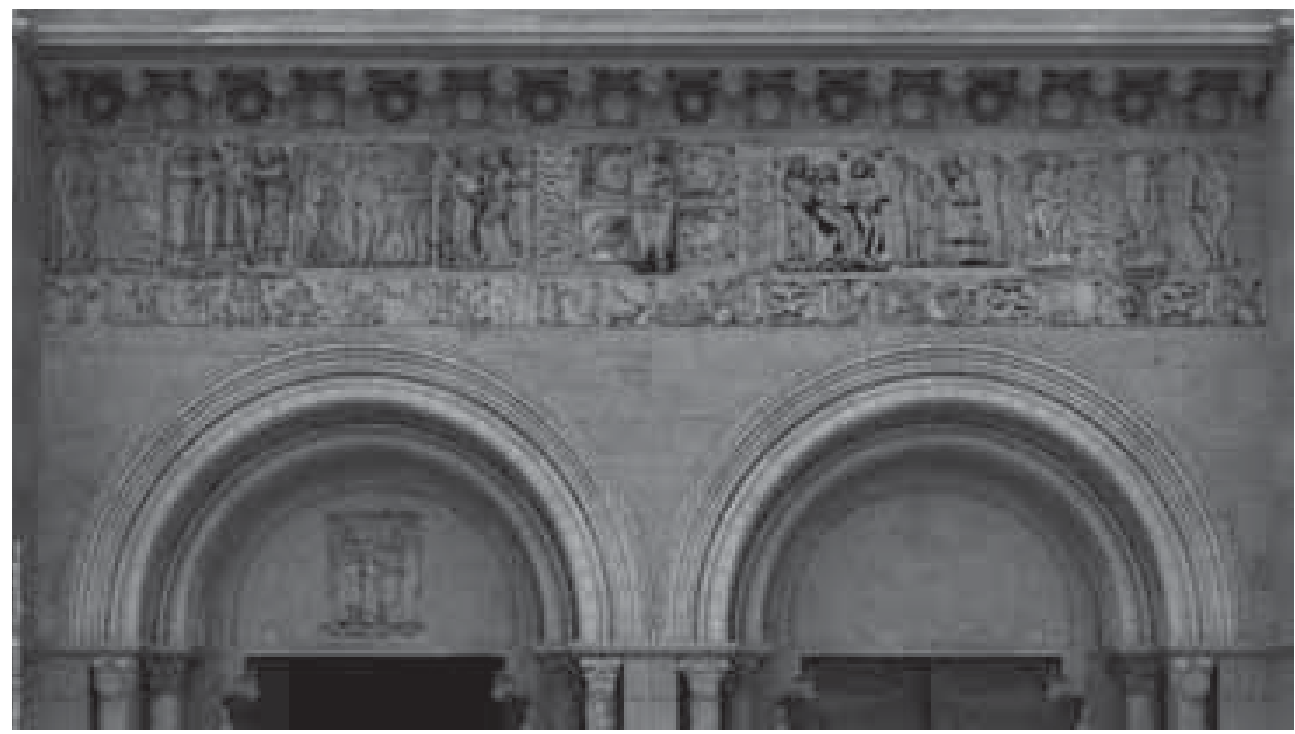

Fig. 6. Reconstrucción 3D de la Porta Francigena: frontispicio. 2010.

terías (Cristo y Símbolo de Mateo). En el lado izquierdo se disponía, de izquierda a derecha, la Creación de Adán y Eva -reaprovechadas en los contrafuertes de Platerías-, el Pecado Original -no conservado-, y la Reprensión de Adán y Eva (Museo de la Catedral). Por su parte, en el lado derecho, de izquierda a derecha, el ciclo proseguía del siguiente modo: la Expulsión de Adán y Eva -reutilizada en el frontispicio de Platerías-y el Trabajo de nuestros primeros padres: Adán trabajando la tierra - no conservado- y Eva amamantando a Caín (fig. 8), reaprovechado en el frontispicio de Platerías. Para la recomposición de las piezas desaparecidas se ha recurrido a ciclos contemporáneos. En el caso del Pecado Original se siguió la escena los marfiles de Salerno (ca. 1085), incidiendo en el hecho de que posiblemente el árbol del Bien y del Mal era una higuera, como sucede en el Tímpano de las Tentaciones de Cristo de Platerías. Por su parte, para la representación de Adán trabajando la tierra se acudió a la Biblia de Moutier-Grandval (Tours, s. IX) (fig. 9), por su posible eco en la iconografía general del ciclo.

Por último, en ambos extremos del friso superior se pasaba del registro narrativo al alegórico. En la parte izquierda, se toma como referente la tipología bíblica, con las lastras de David músico y el Sacrificio de Isaac -reutilizadas ambas en los contrafuertes de Platerías-, mientras que en la derecha se hace hincapié en la exégesis cristiana, con la comparecencia de las Mujeres de las Uvas y del León, prefiguraciones simbólicas de Cristo en su personalidad sufriente y triunfante respectivamente. No deja de ser sugerente el hecho de que estas dos immagines feminarum a las que se refiere el Calixtino se localizaban precisamente junto a la condena al trabajo. Finalmente, para encuadrar perfectamente las lastras del Génesis en un 


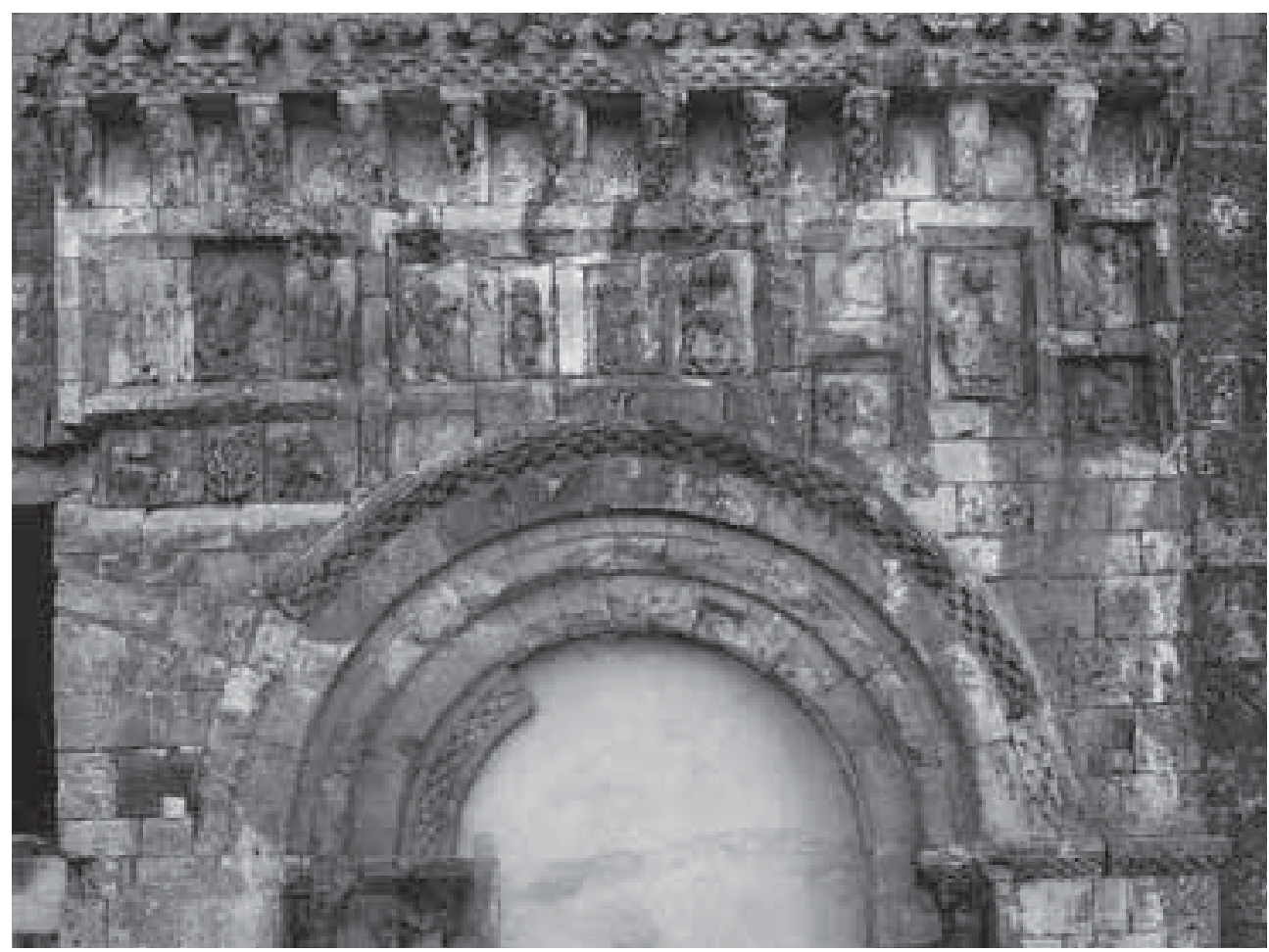

Fig. 7. San Quirce de Burgos, puerta norte, 1125-1150.

espacio evocador del Paraíso, se colocaron lastras vegetales como las conservadas en el frontispicio de Platerías en los extremos de la narración.

Por lo que respecta al friso inferior, éste estaba compuesto de lastras de menores dimensiones: sobre la puerta izquierda, el calendario con los doce meses del año - del que sólo se conserva el relieve del Mes de Febrero en el Museo de la Catedral $-{ }^{18}$, mientras que sobre la puerta derecha se situaba una serie de representaciones profanas que conformaban las consecuencias del Pecado Original: el Centauro-Sagitario y la Sirena -reutilizados en el frontispicio de Platerías-, así como el Ballestero y el Hombre cabalgando un gallo, reaprovechados en la jambas de Platerías. Para su colocación resultó muy sugerente la disposición de un friso muy similar sobre el arco en la puerta norte de San Quirce de Burgos.

Evidentemente la reconstrucción de la iconografía del ciclo del calendario ha sido totalmente hipotética, basada en el ciclo contemporáneo de las pinturas del Panteón

18 M. CastiÑEIRAs, El calendario medieval hispano (ss. XI-XIV): textos e imágenes, Salamanca, 1996, pp. 66-71. 
Real de San Isidoro de León ${ }^{19}$. No obstante, el hecho de que resultaba muy difícil evocar un formato escultórico virtual a partir de las representaciones bidimensionales de las pinturas, llevó a recurrir en algunos casos a ciclos escultóricos del siglo XII con una iconografía similar a la leonesa, como la Porta della Pescheria de la Catedral de Módena (Marzo, Mayo, Julio, Agosto), la puerta sur de Beleña del Sorbe (Guadalajara) (Abril, Junio, Septiembre, Diciembre) o el claustro de Santa Maria de L'Estany (Noviembre).

Por último, la bífora abocinada que daba acceso a la catedral, cuya anchura era igual que la de Platerías, presentaba la particularidad, según el plano de Simón Rodríguez de 1739, de cobijar doce columnas frente a las once de Platerías. De esta manera, cada puerta en la fachada norte estaba flanqueada por seis columnas, tres a cada lado, a la que se añadía en el centro de la bífora una un pilar cuadrangular. Se trataba así de una disposición que evocaba, casi a pie juntillas, a la de la Porte des Comtes (10801090) (fig. 5), tal y como se constata en el hecho de que las columnas internas no estaban dispuestas en derrame, como en Platerías, sino que estaban pareadas como

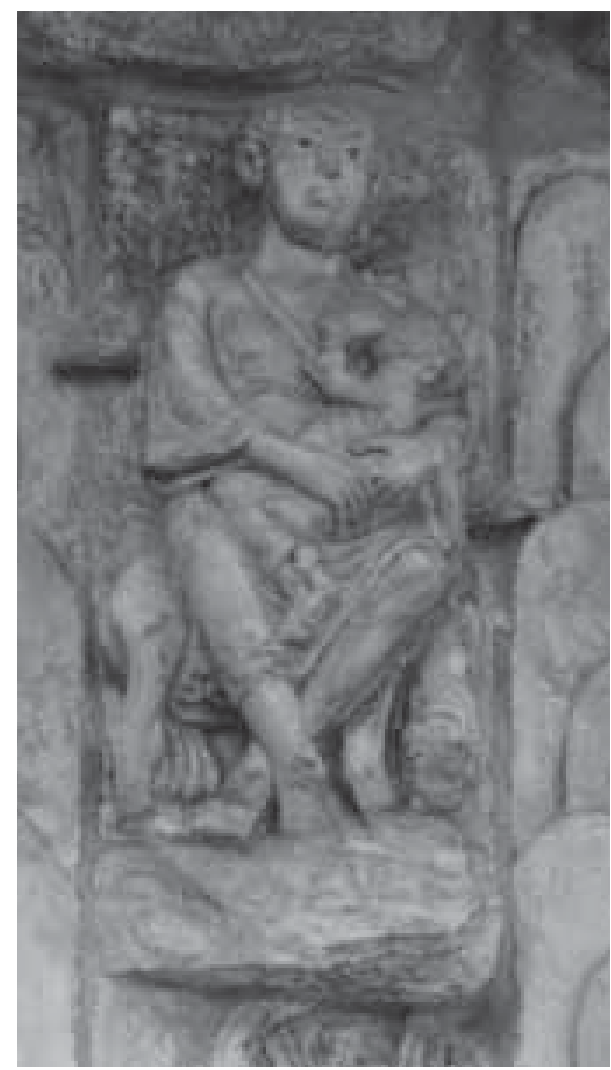

Fig. 8. Catedral de Santiago, brazo sur del transepto, fachada de Platerías, frontispicio: Eva amanta a Caín, 1101-111. Relieve procedente de la Porta Francigena. en el citado monumento francés ${ }^{20}$. Suponemos que las cuatro columnas más internas y menos visibles eran de granito, como la recientemente identificada por F. Singul en el Cruceiro de Santa Maria de Lamas (1775-1800) (Boqueixón, A Coruña) ${ }^{21}$ o como las entorchadas lisas de Platerías, mientras que las más externas -ocho, de las cuales sólo conservamos seis en el Museo de la Catedral- eran de mármol, entorchadas e historiadas. Finalmente, la bífora compostelana se completaba además con otros relieves: la lastra de la Anunciación en el tímpano izquierdo, reutilizada en el friso de Platerías; unas mochetas en forma de cabeza de buey, como después será habitual en el románico gallego; así

\footnotetext{
19 Ibid., pp. 71-75.

20 Fernández GonzÁlez, "Un viejo plano olvidado".

21 F. Singul, "Fuste granítico probablemente perteneciente a una columna de la fachada del Paraíso de la Catedral de Santiago”, Compostela y Europa. La historia de Diego Gelmírez, pp. 182-187.
} 


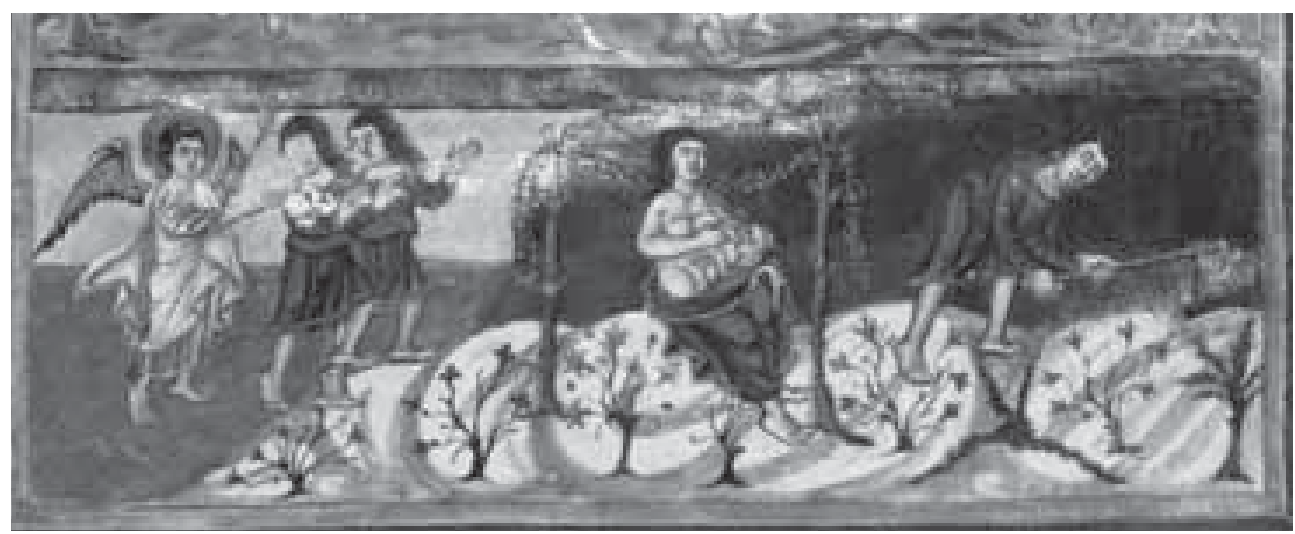

Fig. 9. Biblia de Moutier-Grandval, Tours, 840, Londres, BL, Add. 10546, f. 5v: Expulsión del Paraíso, Los trabajos de Adán y Eva.

como las figuras de apóstoles en las jambas, a las que habría pertenecido, según V. Nodar y S. Fernández, un San Pedro reutilizado en el friso de Platerías ${ }^{22}$.

\section{El viaje como motor artístico: de los itinerarios a Roma a la creación de un "arte gelmiríano"}

No cabe duda alguna que el análisis pormenorizado de la estructura espacial, arquitectónica y decorativa de la Porta Francigena pone de manifiesto la capacidad de citación del monumento gelmiríano con respecto a otras obras, precedentes y coetáneas, dispersas en una amplia geografía europea. De hecho, tanto desde el punto de vista tipológico - puerta bífora- como programático - grandes ciclos narrativos al servicio de la exaltación del epos cristiano-, la fachada compostelana encuentra sus congéneres en el arte monumental entonces emergente en tierras del Sur de Francia y en la convulsa Italia de la Reforma Gregoriana. No obstante, dicha familiaridad no es fruto de un papel pasivo o secundario de Compostela en la formulación del gran portal románico historiado, sino más bien de todo lo contrario. Lamentablemente el auge de la peregrinación a Santiago hacia 1100 ha sido entendido muchas veces como la única forma que la ciudad tuvo de recibir "influencia" artística, como si fuese -utilizando una metáfora de A. K. Porter-, la desembocadura de un río, en el que confluyen muchos afluentes procedentes de las más lejanas tierras de Europa: The pilgrimage road may be compared to a great river, emptying into the sea at Santiago, and formed by many tributaries which have their sources in the far regions of Europe $e^{23}$.

22 S. Fernández PÉrez y V. NodAr, "Un proyecto de reconstrucción hipotética de las portadas del transepto de la Catedral de Santiago", p. 608, 612, fig. 3.

23 A. K. Porter, Romanesque Sculpture of the Pilgrimage Roads, I, Boston, 1923, p. 175. 
No obstante, como veremos, la historia de Diego Gelmírez y la epopeya de sus viajes entre los años 1100 y 1105 parecen correr paralelos a las ambiciones políticas, eclesiásticas pero también artísticas de la sede compostelana. Como resultado, su figura se convierte en un indiscutible patrono de la ciudad o, más aún, si queremos utilizar la imagen que de él nos ofrecen Manuel Murguía y Ramón Otero Pedrayo, en un verdadero "príncipe de la Cristiandad"24. Su capacidad económica, su poder fáctico y sus ansias de transformar Compostela en un centro de primera magnitud le permitieron actuar, en buena medida, como un verdadero comitente. De hecho, no cabe duda que es a través de sus dos largos viaje a Roma, que él y su séquito tuvieron conocimiento directo de las grandes obradores de su tiempo y de sus promotores, lo que le permitió, a vista de los resultados, emular los mejores modelos arquitectónicos y litúrgicos y contratar destacados artistas foráneos, pero también realizar propuestas artísticas ambiciosas y osadas como cabía a una sede apostólica que quería ser metropolitana y ansiaba alcanzar algún día la dignidad de patriarcado de Occidente ${ }^{25}$.

Por todo ello, el viejo concepto de "influencia" o de "artista itinerante" que "peregrina" a lo largo del Camino de Santiago no resulta válido y debe ser revisado en función del papel omnipotente de un comitente ${ }^{26}$, Gelmírez, dispuesto a recorrer miles de millas en busca del progreso de su sede o a invertir grandes cantidades de oro y plata en la construcción de un gigantesco transepto. El Camino de Peregrinación se convierte así no en una meta artística sino en la vía que el prelado aprovecha para conectarse "simultáneamente" con el progreso de los grandes centros creadores de la Europa románica-Toulouse, Conques, Cluny, Módena, Romaen beneficio de una cultura agonística, de la competencia y del intercambio ${ }^{27}$. Un breve recorrido por las peculiaridades de la primitiva Porta Francigena y de su "melliza" de Platerías resulta suficiente para entender donde están las elecciones y obsesiones de este comitente viajero, que convirtió a Compostela en la vanguardia del arte románico europeo.

24 R. Villares, "Ventura de Diego Gelmírez en la tradición cultural galeguista", Compostela y Europa. La historia de Diego Gelmírez, pp. 188-201, esp. 194-200.

25 Fundamentales para entender el perfil de Gelmírez como comitente de las artes son los trabajos de J. Filgueira Valverde (“Gelmírez, constructor”, Historias de Compostela, Vigo, 1982, pp. 37-75) y de SeraFín Moralejo ("El patronazgo artístico de Diego Gelmírez (1100-1140): su reflejo en la obra e imagen de Santiago", Pistoia e il Cammino de Santiago. Una dimensione europea della Toscana medioevales. Atti del Convegno Internazionale di Studi, Pistoia, 28-30 settembre 1984, Nápoles, 1987, pp. 245-272). Véase también mi reciente contribución: "Diego Gelmírez, un committente viaggiatore: dalla Porta Francigena all'altare maggiore della cattedrale di Santiago", Medioevo: i committenti, A. C. Quintavalle (ed.), Atti del Convegno Internazionale di Studi, Parma, 21-26 settembre 2010, Milán, 2011, pp. 268-280.

26 Una buena base metodológica para la discusión de estos conceptos en S. Moralejo, "Artistas, patronos y público en el arte del Camino de Santiago", “Compostellanum”, XXX (1985), pp. 395-430.

27 Para una revisión del concepto de cultura agonística y de intercambio, formulada por A. K. Porter en 1923 con respecto al arte de los Caminos de Peregrinación, remito a mi reciente contribución: “Compostela, Bari y Jerusalén: tras las huellas de una cultura figurativa en los Caminos de Peregrinación”, Ad Limina. Revista de Investigación del Camino de Santiago y de las Peregrinaciones, I (2010), pp. 15-51. 
Desde un punto tipológico, las fachadas del transepto compostelano se han puesto siempre en directa relación con las de la basílica de Saint-Sernin de Toulouse, en particular, con la Porte des Comtes (ca. 1080-1090) (fig. 5), por su estructura de puerta bífora abocinada, con capiteles historiados, decorada con relieves de enjuta en el frontispicio y coronada por un cornisa de canes figurados. A estos elementos arquitectónicos figurados se sumaron, años más tarde, en la Porte Miegèville (ca.

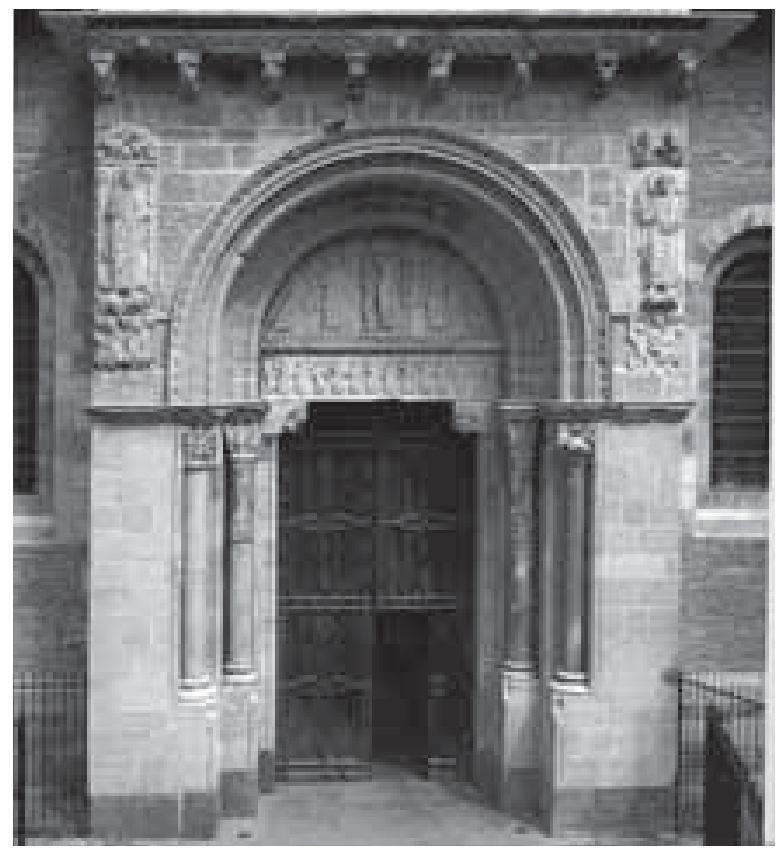

Fig. 10. Basílica de Saint-Sernin de Toulouse, cuerpo de las naves, lado sur: Porte Miègeville, ca. 1100-1105. $1100-1105)^{28}$, otros elementos esculturados como mochetas, tímpano y metopas (fig. 10), que también se encuentran en las fachadas gelmiríanas. No obstante, con respecto a Toulouse, hay que reconocer que las portadas compostelanas (1101-1111) fueron un verdadero laboratorio de experiencias, en el que se desarrollaron fórmulas apenas esbozadas en Toulouse. En primer lugar, cada uno de elementos arquitectónicos que las conformaban fue susceptible de figuración historiada, con una gran variedad de formatos que abarcaba, como en Toulouse, capiteles, mochetas, enjutas, tímpano, enjutas, canes y metopas, pero que a la vez incorporaba novedades como columnas historiadas, placas figuradas de jamba y frisos narrativos. En segundo lugar, las fachadas compostelanas hicieron crecer el espacio de los frontispicios, con el objeto de convertirlos en verdaderos frisos narrativos o frontis de estatuas. Es en Italia, y no en Francia, donde se encuentran las primeras formulaciones de estos formatos: si en la Catedral de Módena, entre 1099 y 1106, el taller de Wiligelmo realizaba un friso del Génesis para cubrir la entrada principal del edificio (fig. 11); en la de Cremona, entre 1107 y $1117^{29}$, ese mismo taller colocaba cuatro profetas que flanqueaban, como en la primitiva Porta Francigena y Platerías, la entrada central de

28 Para la cronología de las puertas tolosanas remito al reciente trabajo de D. y Q. CAZES, Saint-Sernin de Toulouse. De Saturnin au chef d'oeuvre de l'art roman, Toulouse, 2008.

29 Con respecto a las fechas de Módena y Cremona, cfr., A.C. Quintavalle, Willigelmo e Matilde. L'officina romanica, Milán, 1991. 


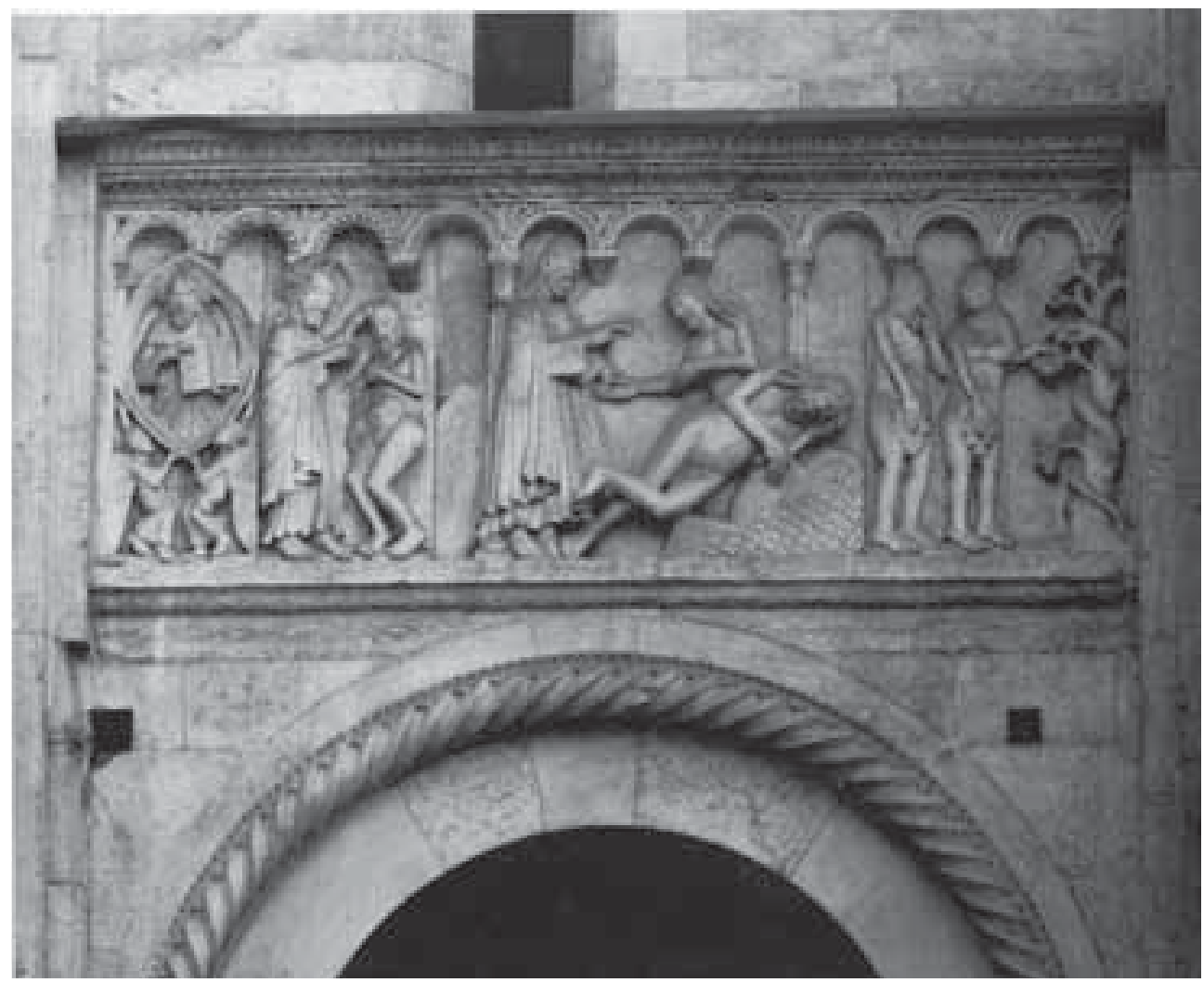

Fig. 11. Catedral de Módena, fachada occidental: Wiligelmo, friso del Génesis, ca. 1099-1106.

la fachada (figs. 12-13), bajo un friso con el ciclo de Adán y Eva. Por último, para las columnas figuradas compostelanas, sobre todo en el caso de la Francigena, los marmolistas romanos que elaboraron a finales del siglo XI las columnas salomónicas de San Carlo a Cave (Lacio) (fig. 14) y de Trinità dei Monti (Roma) parecen haber sido el punto de referencia de Compostela (fig. 15) ${ }^{30}$.

Desde una perspectiva más temática y programática, las fachadas compostelanas presentan un modo genuinamente narrativo, fresco y directo, que no duda en incorporar lo profano a la historia bíblica, como en el Portal Occidental de Santa Fe de Conques ${ }^{31}$. De hecho, este lenguaje figurativo animado y desenfadado, propio de

30 M. CastiñeIras, "Roma e il programma riformatore di Gelmírez nella cattedrale di Santiago", Medievo: immagini e ideologie, V Convegno Internazionale di Studi. Parma, 23-27 settembre 2002, A. C. Quintavalle (ed.,), Parma-Milán, 2005, pp. 211-226. V. NodAR, "Colonne salomoniche della chiesa della Santissima Trinità dei Monti a Roma e di San Carlo a Cave", Compostela y Europa. La historia de Diego Gelmírez, fichas cat. $\mathrm{n}^{\mathrm{o}}$ 19-20, pp. 346-348.

31 M. CAstiñeiras., "Da Conques a Compostella: retorica e performance nell'era dei portali parlanti", Medievo: Immagine e Memoria, Atti del XI Convegno Internazionale di Studi, Parma, 23-28 settembre 2008, 


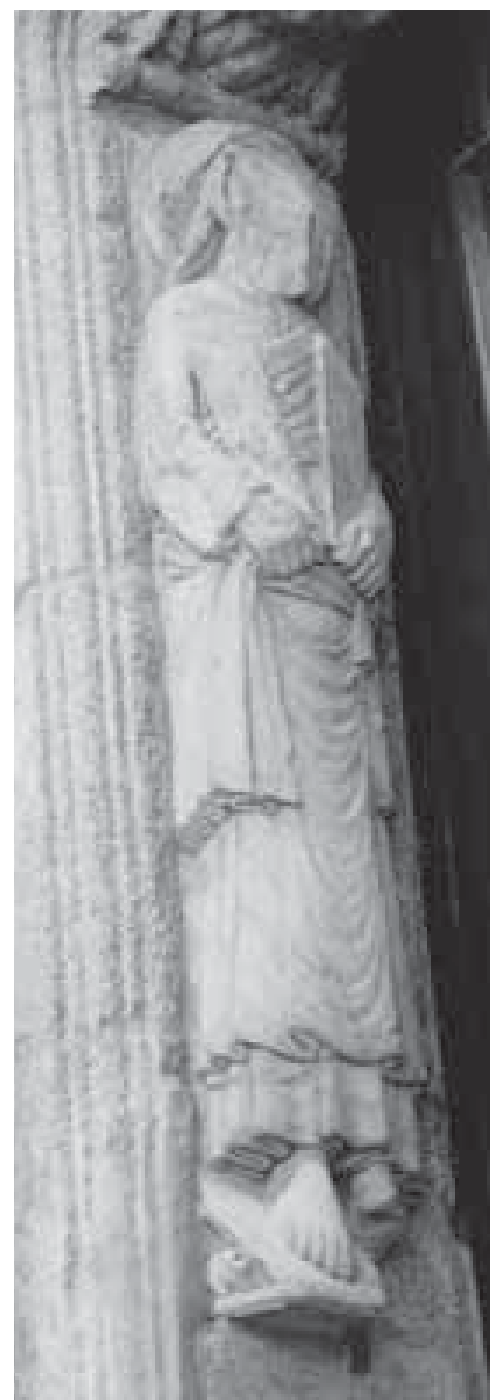

Fig. 12. Catedral de Santiago, fachada sur (Platerías), ingreso izquierdo, jamba izquierda: Maestro de las Tentaciones, Moisés, 1103-1105. grandes centros de peregrinación, adquiere en Compostela y Conques un carácter tan monumental que convierte a sus portales en verdaderos movie marquee (marquesinas de cine), tal y como en su día sugirió S. Moralejo. No obstante, con respecto a Conques, Compostela hace explícita su adhesión a los principios del arte de la Reforma Gregoriana empleando fórmulas similares a la de los monumentos italianos. Como en el Génesis de Módena, donde Dorothy Glass ha sugerido una inspiración en el frontispicio de una Biblia Atlántica como la del Panteón ${ }^{32}$, en la Porta Francigena el ciclo de Adán y Eva posiblemente seguía el frontispicio de una Biblia carolina, como la de Tours $^{33}$. Del mismo modo, como en Módena o Roma, se detectan referencias explícitas a la Antigüedad paleocristiana, bien a través del conocimiento de las composiciones de los sarcófagos antiguos - ciclo de la Pasión de Platerías-, bien a través de la cita de genuinos motivos decorativos, como los roleos de vid que cubren todavía las lastras verticales del frontispicio de Platerías o las célebres columnas con putti vendimiadores de la primitiva puerta norte ${ }^{34}$.

¿Cómo explicar pues el gran salto hacia delante que supusieron las fachadas compostelanas con respecto a las experiencias previas de los talleres activos en el Camino de Santiago o de la propia geografía europea? En mi opinión, la clave está en los viajes emprendidos por Diego Gelmírez y miembros del la curia compostelana en los primeros años del siglo XII (fig. 16). En dos ocasiones Gelmírez recorrió el Camino Francés en España y parte de las vías de peregrinación francesas, camino de Roma, en busca de nuevas dignidades para

A. C. Quintavalle, (ed.), Milán-Parma, 2009, pp. 233-251.

32 D. Glass, "Leggendo il Genesi nelle sculture della cattedrale di Modena", en Matilde e il tesoro dei Canossa : tra castelli, monasteri e città , Arturo Calzona (ed.), Milano, 2008, pp. 176-187, esp. 179, 182, fig. 7.

${ }^{33}$ M. CAstiñeiras., "Didacus Gelmirius, patrono de las artes. El largo camino de Compostela: de periferia a centro del Románico", Compostela y Europa. La historia de Diego Gelmírez, pp. 32-97, esp. 66.

${ }^{34}$ M. CAStiÑEIRAs, "La catedral de Santiago", "Didacus Gelmirius, patrono de las artes". 


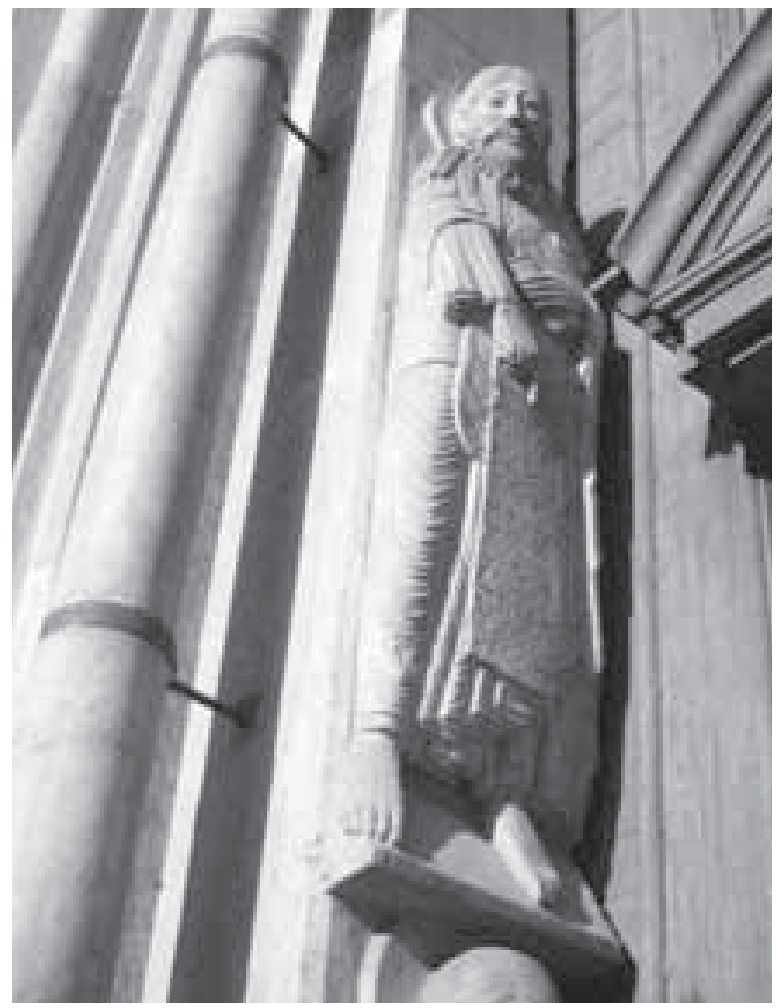

Fig. 13. Catedral de Cremona, fachada occidental, jamba izquierda: Wiligelmo, Jeremías, 1107-1117.

él y $s u$ diócesis. Del primero, realizado en 1100 , con apenas 30 años, casi nada sabemos, salvo que fue ordenado subdiácono en la Ciudad Eterna el 18 de marzo de 1100 , tal y como recoge la Historia Compostelana (I, VII, 1-2) ${ }^{35}$. Con toda probabilidad, Gelmírez emprendió posiblemente un largo viaje hasta Puente la Reina y de allí tomaría el tramo aragonés que, pasando por Jaca, conectaba con la via tolosana, la cual podría haber seguido por tierra hasta conectar en Luni (Liguria), con la via francigena italiana, o bien desviarse hasta el puerto de Marsella para llegar en barco a Génova o a el puerto de Pisa, desde donde alcanzaría la francigena en Lucca. Dos hechos parecen corroborar este último tramo tolosano combinado con un embarque marítimo ${ }^{36}$. En primer lugar, el buen conocimiento que el Libro V, 9 del Códice Calixtino tiene de la ciudades de Saint-Gilles y Arles, cuyas reliquias, relicarios -en especial, el Arca de San Gil-, y lugares santos son descritos en la Guía de forma minuciosa ${ }^{37}$. En segundo lugar, la existencia de itinerarios similares realizados desde la Península en el siglo XII, como el emprendido por el rabino Benjamín de Tudela hacia 1160, que tras recorrer el camino de Saint-Gilles, realiza en barco el trayecto entre Marsella y Génova, para después continuar hasta Pisa y Lucca ${ }^{38}$. Estas dos ciudades italianas están, de hecho, muy

35 Historia Compostelana, I, 7, 1-2, trad. E. Falque Rey, Madrid, 1994, pp. 85-86.

36 Los argumentos para la reconstrucción de este viaje han sido expuestos anteriormente por mí en: "Platerías: función y decoración de un "lugar sagrado", Santiago de Compostela: ciudad y peregrino, Actas del V Congreso Internacional de Estudios Jacobeos, Xunta de Galicia, Santiago, 2000, pp. 289-331, esp. 294-295; "El porqué de una exposición itinerante. Diego Gelmírez, genio y espíritu viajero del Románico", Compostela y Europa. La historia de Diego Gelmírez, pp. 16-29, esp. p. 20-21 (mapa).

37 CC, V, 8, trad. cit., pp. 525-531.

38 Libro de viajes de Benjamín de Tudela, introd., trad. y notas de J.R. MAgdalena Nom de Déu, Barcelona, 1989, pp. 58-59. 
ligadas a la política militar y eclesiástica de Gelmírez. Así, de Pisa procedía un tal Frixón, instruido en el arte de navegar, que se hizo cargo de la marina compostelana establecida en Padrón y los puertos de Arousa ${ }^{39}$, mientras que en Lucca residía entonces el archidiácono Gregorio, futuro cardenal de San Crisógono de Roma (1109-1111) y autor del Polycarpus, libro de cánones dedicado a Diego Gelmírez hacia 1109, en cuyo proemio se deduce que ambos se habían conocido anteriormente: petistis jam dudum et hoc saepe (...) librum canonum (Vat. Lat. 1354, f. 1r) ${ }^{40}$.

Aunque no sabemos exactamente las etapas que siguió la comitiva, es muy posible que el intrépido Gelmírez hubiese viajado entonces en el más estricto anonimato por miedo a ser capturado o reconocido por el depuesto obispo de Compostela, Diego Peláez (1075-1088), que vivía exilia-

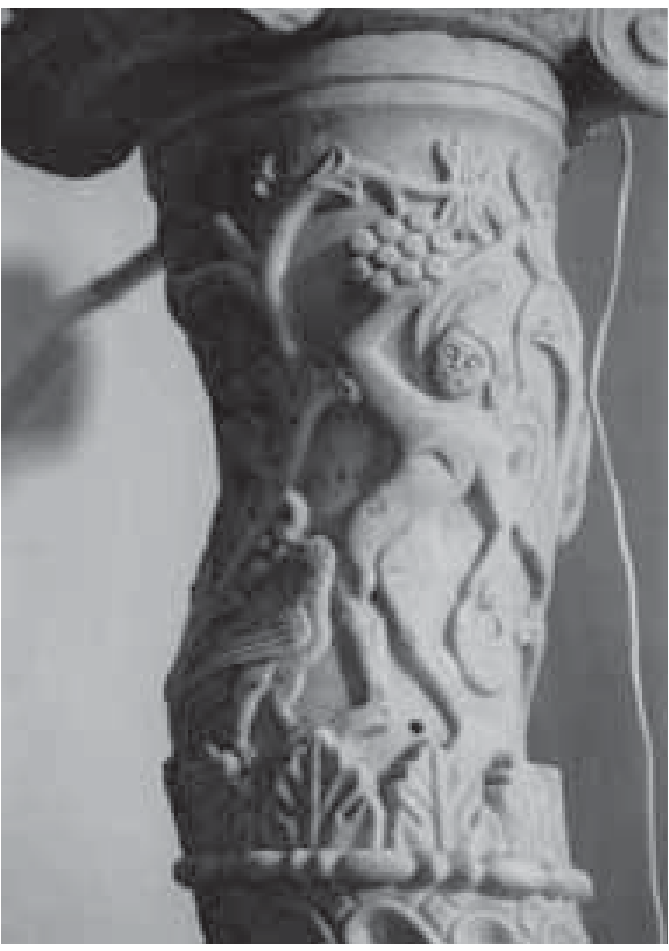

Fig. 14. San Carlo a Cave (Lacio), columna salomónica, ca. 1093. do en la Corte de Pedro I de Aragón y Navarra (1094-1104) y que todavía albergaba deseos de volver. De ahí las reticencias, meses después, de la curia compostelana a que Gelmírez repitiese en 1101 ese viaje por tierras de Aragón para ser consagrado obispo en Roma (HC I, $9,1)^{41}$. Considero, pues, poco probable otras posibilidades, como la que Gelmírez hubiese evitado en 1100 el reino de Aragón a través del Reino Taifa de Zaragoza para alcanzar el condado de Barcelona y desde allí embarcar rumbo al puerto pisano. Cabe recordar que entonces la seguridad de la navegación en esa franja central

39 "Pues mandó construir con gran gasto una birreme, que se llama vulgarmente "galera", y una vez construida la entregó a un joven llamado Frixón, oriundo de la ciudad de Pisa, de buenas costumbres y muy experto en artes náuticas, para que navegando con ella se dirigiera contra la tierra de los amorreos", HC, II, 85, trad. cit., pp. 449-450; Filgueira Valverde, “Gelmírez, constructor”, pp. 71-72. La Compostelana fecha el acontecimiento tras la consecución del arzobispado por Gelmírez (HC, II, 85, trad. cit. P. 449), es decir, después de 1120 .

40 U. Horst, Die Kanonensammlung Polycarpus von Gregor von S. Crisogono. Quellen und Tendenzen, Monumenta Germaniae Historica, Hilfsmittel, 5, Munich, 1980, pp. 3-4; M. CASTIÑEIRAS, "Platerías: función y decoración", pp. 294-295; V. Nodar, "Polycarpus", Compostela y Europa. La historia de Diego Gelmírez, ficha cat. $\mathrm{n}^{\mathrm{o}} 22$, pp. 354-355.

41 HC, I, 9, 1, trad. cit., p. 86. 

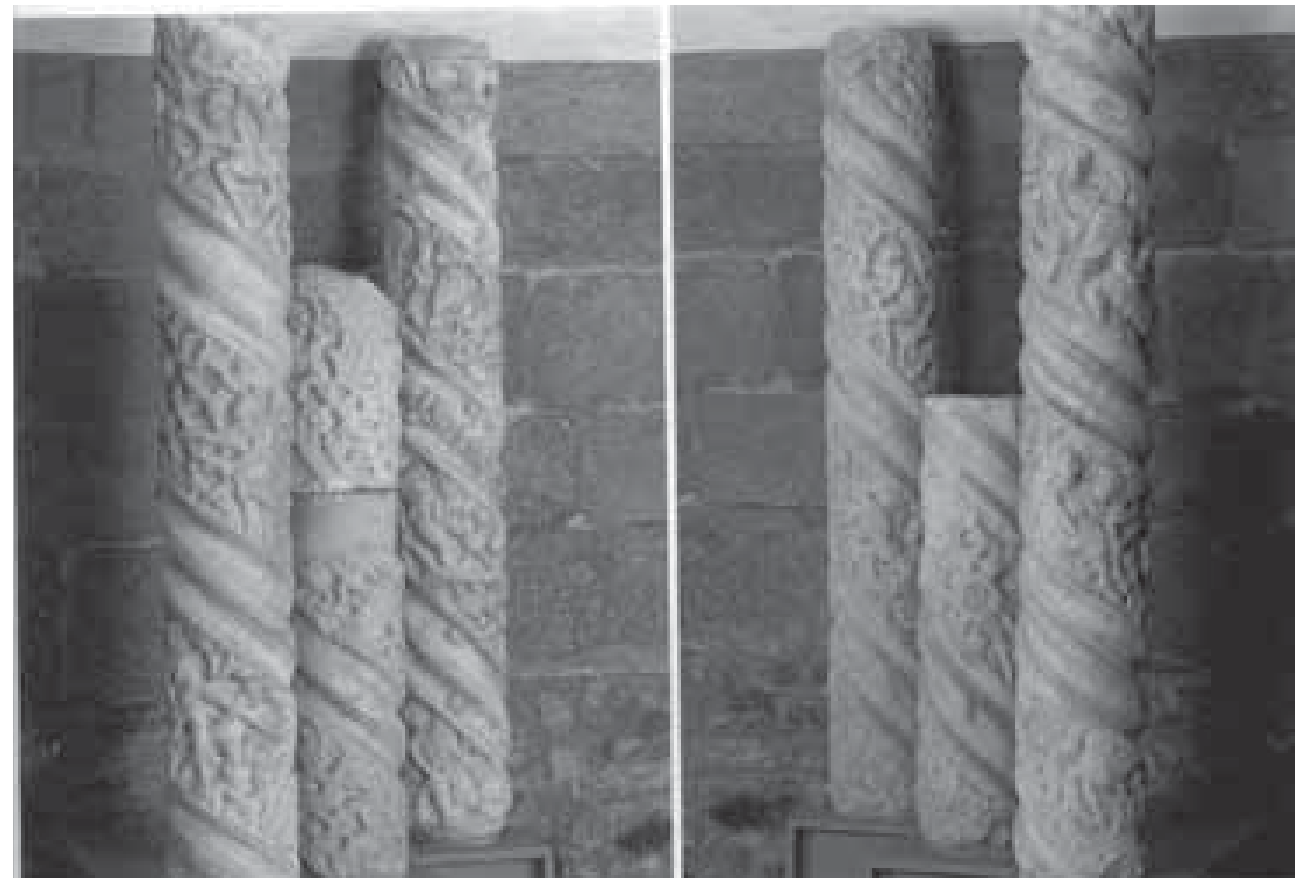

Fig. 15. Maestro de la Columnas Entorchadas, columnas entorchadas de la primitiva puerta norte, ca. 11011111. Museo de la Catedral de Santiago.

del Mediterráneo Occidental estaba amenazada por los constantes ataques de los piratas sarracenos de Mallorca. Habrá, pues, que esperar a la expedición catalanopisana de 1114-1115, con la conquista de Mallorca, para asegurar un tránsito fluido por dichas aguas ${ }^{42}$.

Una vez vuelto de Roma como subdiácono en 1100, Gelmírez tuvo que esperar hasta la Pascua del año siguiente, el 21 de abril de 1101, para ser consagrado obispo en Compostela. Según Gordon Biggs, muy probablemente Diego tuvo que ser ordenado, a toda prisa, diácono y presbítero en los días anteriores, quizás el 6 y el 20 de abril $^{43}$. Unos años después, en 1105, fallecidos Pedro I y probablemente Diego Peláez - cuya última mención documental se fecha en Leyre en 1104-, Gelmírez emprende un segundo viaje -bien detallado en la Historia Compostelana- en el que no duda en atravesar las montañas vasco-navarras (HC I, 16, 1) 44 $^{44}$ Muy posiblemente la elección del tramo navarro para llegar a Ostabat, pasando por Pamplona y Roncesvalles, para después alcanzar la via tolosana, se explica en el marco de

42 Sobre la breve conquista de Mallorca en 1114-1115, véase J. E. RuIz DoméNEC, Ricard Guillem o el somni de Barcelona, Barcelona, 2001, pp. 151-158.

43 G. Biggs, Diego Xelmírez, Vigo, 1983, pp. 51 y 298, nota 211 (1 ${ }^{\mathrm{a}}$ ed. ing. 1949).

44 HC I, 16, 1, trad. cit., p. 100. 


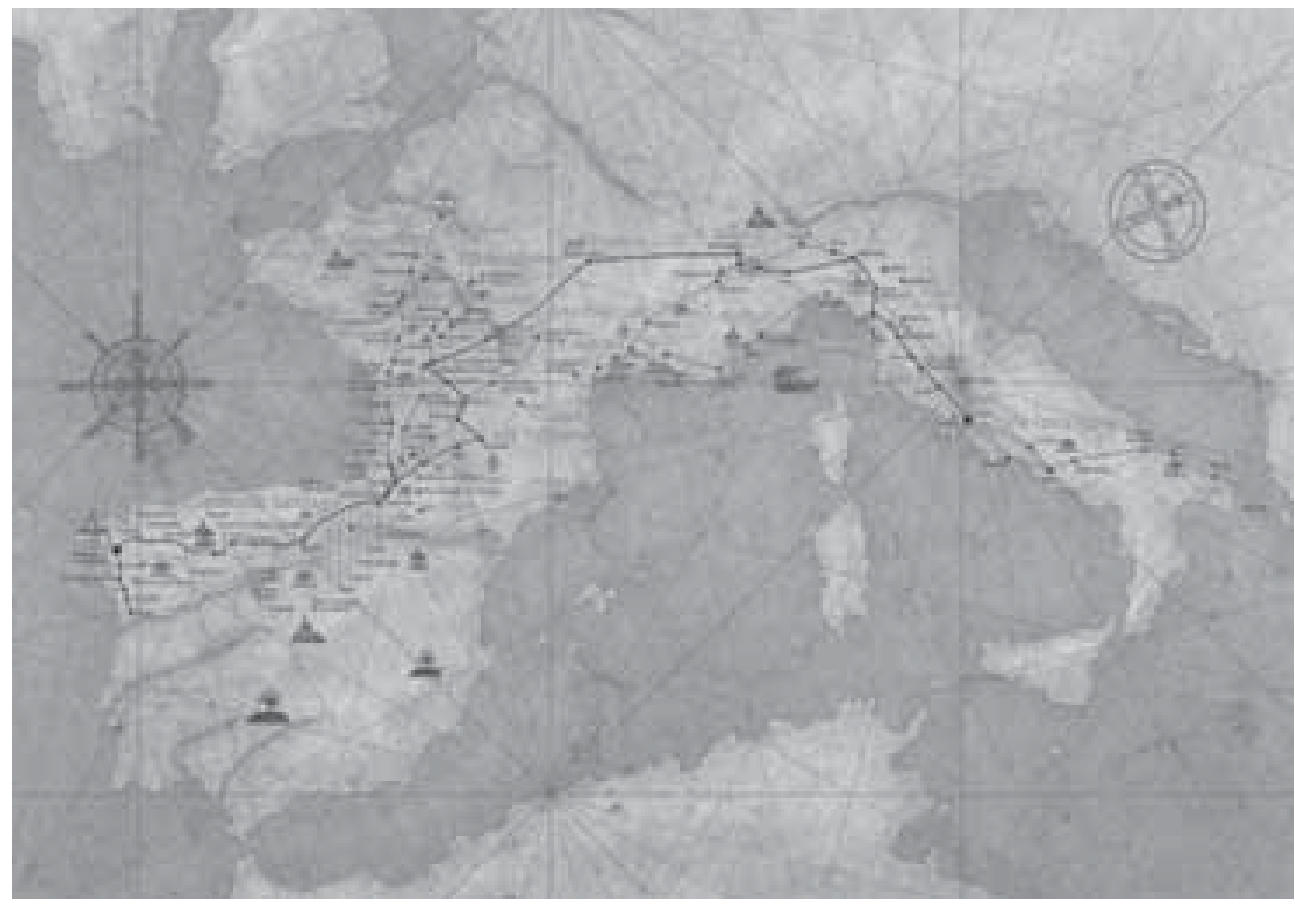

Fig. 16. Itinerarios de los viajes de Diego Gelmírez a Roma en 1100 y 1105 . Realizado bajo la dirección científica de M. Castiñeiras para la Exposición: Compostela y Europa. La historia de Diego Gelmírez, ParísRoma-Santiago 2010.

las buenas relaciones existentes entre el nuevo prelado compostelano y Pedro de Rodez, obispo de Pamplona, quien en 1101 había contratado para su fábrica a Esteban, maestro de obras de Santiago, y que a la vuelta del periplo gelmiríano le pidió a éste consagrar la capilla de Santa Fe en la cabecera de la catedral compostelana $(\mathrm{HC}, \mathrm{I}, 19,)^{45}$.

El itinerario del viaje de 1105 sorprende porque fue aprovechado para adentrarse en tierras galas, camino de Cluny, (fig. 16). Gelmírez siguió primero la via tolosana, visitando Auch y Toulouse, para luego tomar la via podiensis, con parada en Moissac y Cahors -y en mi opinión, aunque no queda recogido en la Compostelana, en la abadía de Conques-, y seguidamente, tras desviarse por Uzerche hacia la via lemosina, en ella hace parada en Limoges, St. Léonard de Noblat y Sainte Valerie, llega finalmente a Cluny, donde es recibido por el todopoderoso abad Hugo, celebrando una misa la festividad de San Miguel (29 de septiembre) de $1105^{46}$. Desde allí alcanzó los valles de Moriana y en la ciudad de Susa baja por la via

45 HC I, 19, trad. cit., p. 109.

46 HC I, 16. 2 (Auch), 3 (Toulouse-Moissac-Cahors), 4 (Uzerche-Limoges-Sainte Valerie), 5 -6v(Cluny), trad. cit., pp. 100-101. 
francigena italiana hasta Roma, disfrazado de soldado $^{47}$, pasando probablemente por, Pavia, Piacenza, Fidenza, Luni, Lucca, Altopascio, Siena, S. Quirico d'Orcia, Viterbo y Sutri. Para la reconstrucción hipotética de este itinerario a través de la francigena, contamos con el precedente de Sigeric, arzobispo de Canterbury, que tras recibir el palio en Roma, volvió a su sede por ese mismo camino hasta Pavía, o con la peregrinación del abad islandés, Nikulas de Munkathvera (1151-1154) o la del rey Felipe II Augusto a su retorno de la Tercera Cruzada en $1191^{48}$. No puede descartarse, sin embargo, que la comitiva compostelana haya tomado, en la ida o en la vuelta, el trazado de la Via Aemilia, de Piacenza a Forlí, pasando por Parma, Módena y Bologna, para luego bajar por Bagno di Romagna, Arezzo, Perugia, Spoleto, Foligno, Rieti y Roma, tal y como hizo el monje de St. Albans, Matthew Paris en la primera mitad del siglo XIII ${ }^{49}$.

Finalmente, el 31 de octubre de 1105, en la basílica romana de San Lorenzo Extramuros, Gelmírez recibió el palio de manos del Papa Pascual II (1099-1118) ${ }^{50}$. Aunque tradicionalmente el privilegio se venía fechando en las ediciones de la Historia Compostelana como de 1104, Ludwig Vones, a partir del análisis de la copia del documento en el Tumbo B del Archivo de la Catedral de Santiago (fols. 225v226r), estableció definitivamente que el viaje y el hecho tuvieron lugar en $1105^{51}$.

Desde un punto de vista artístico, resulta obvio el impacto y las consecuencias de los itinerarios gelmiríanos de 1100 y 1105 . En ambas ocasiones, la comitiva compostelana tuvo la oportunidad de conocer, de primera mano, los grandes centros creadores del arte románico del momento, como los obradores abiertos de Jaca, Toulouse, Conques y Cluny, u obras recién concluidas como el Claustro de San Pedro de Moissac. No hay que olvidar que muchas de las peculiaridades tipológicas (puerta bífora con relieves), temáticas (Apostolados, Teofanías, repertorio profano) y programáticas (exaltación de la vita apostolica, condena de los vicios) de las fachadas compostelanas derivan de los citados monumentos galos. Del mismo modo, en su periplo italiano, Gelmírez y sus acompañantes pudieron contemplar el resurgimiento del arte monumental promovido por la ideología de la Reforma Gregoriana, que recurriendo a los modelos paleocristianos quería retornar a los orígenes de la Iglesia y enseñar, además, los dogmas de la fe a través de las imágenes en una especie de "escritura para iletrados". De hecho, la amplitud del programa de la Porta Francigena, con temas como los meses, el repertorio profano

47 HC I, 17, 1,(Moriana-Susa-Roma), trad. cit., p. 103-104.

48 R. Stopani, La Via Francigena. Una strada nell'Italia del Medioevo, Florencia, 1988, pp. 16-25, 53-70, B. Birch, Pilgrimage to Rome in the Middle Ages. Continuity and Change, Woodbridge, Suffolk, 1998, pp. $10-11$.

49 Cfr. Stopani, La Via Francigena, pp. 98-99; Birch, Pilgrimage to Rome, pp. 9, 44, 47-48.

50 HC I, 17, 2, trad. cit., pp. 104-105.

51 L. Vones, Die Historia Compostellana und die Kirchenpolitik des Nordwestspanischen Raumes 10701130, Colonia, 1980, pp. 160-161, notas 60 y 60a. Consúltese una correcta edición del documento en Tumbo B de la Catedral de Santiago, M. T. González Balasch (ed.), Santiago, 2004, pp. 525-527. 
y la historia del Génesis, y su claro abuso en la utilización del friso historiado y figuras de jamba, enlazan con las preocupaciones de las fachadas de Wiligelmo en Módena (Puerta Occidental y Porta della Pescheria) y en Cremona.

No obstante, lo que subyace en estos viajes es la firme adhesión compostelana al modelo estético-ideológico de una Roma papal, paleocristiana y antigua. Con ello, Gelmírez supera las viejas reticencias de los pontífices a la sede jacobea, que se habían concretado en la excomunión del obispo Cresconio por León IX en el Concilio de Reims de $1049^{52}$. La condena tenía que ver con la costumbre de los obispos de Iria-Santiago de arrogarse el título de "obispo de la sede apostólica". Ahora bien, con el reformista Gelmírez, una vez eliminado su opositor Diego Peláez, el nuevo camino de la futura sede metropolitana parecía ir de la mano de Roma. Quizás éstos fueron los pensamientos del joven Gelmírez, cuando en 1100 se postró delante de la confessio de San Pedro del Vaticano, ante la doble fila de columnas salomónicas de la pérgola, para recibir, según el ritual canónico, el subdiaconado ${ }^{53}$. Esas mismas reflexiones lo asaltarían en el momento de recibir el palio en la antigua basílica cementerial de San Lorenzo Extramuros, en medio de sarcófagos antiguos y paleocristianos. Las consecuencias artísticas que ambos momentos simbólicos tuvieron sobre la obra compostelana fueron, en primera instancia, señaladas por S. Moralejo $^{54}$, tanto en las columnas entorchadas procedentes de la Porta Francigena, como en la sistematización de un frontal y un baldaquino de plata en el altar mayor. Sus conclusiones, no obstante, fueron reformuladas con nuevas aportaciones por mí en el año 2002, al proponer una inspiración directa del Maestro de la Columnas Entorchadas en las obras de marmolistas romanos coetáneos, del Maestro de la Porta Francigena en el repertorio dionisíaco del sarcófago tardoantiguo reutilizado como tumba del Papa Dámaso II († 1048) en San Lorenzo Extramuros así como al señalar todo lo que de emulación de las basílicas romanas tiene la creación de una confessio bajo la parte trasera del altar de Santiago ${ }^{55}$. A ello hay que añadir la cita paleocristiana y lateranense del friso de la Pasión de Cristo del Maestro de Conques (o de las Tentaciones) en Platerías ${ }^{56}$.

No cabe pues, duda alguna, que las portadas del transepto compostelano y la nueva sistematización del altar mayor jacobeo son productos directos de los viajes de Gelmírez por tierras galas e italianas. Sólo a partir de 1100-1101 puede hablarse de un verdadero "arte gelmiríano", cuya época dorada finaliza en torno a 1122-

52 A. Isla Frez, Memoria, culto y monarquía hispánica entre los siglos X y XII, Jaén, 2006, pp. 97-98

53 Para una descripción de la pérgola de San Pedro de Roma y el rito de las ordenaciones, véase: $\mathrm{S}$. DE BlaAuw, Cultus and decor. Liturgia e architettura nella Roma tardoantica e medievale, Ciudad del Vaticano, 1994, pp. 553-554, 604.

54 S. Moralejo, "El patronazgo artístico de Diego Gelmírez".

55 M. Castiñeiras, "Roma e il programma riformatore di Gelmírez nella cattedrale di Santiago", Medievo: immagini e ideologie, V Convegno Internazionale di Studi. Parma, 23-27 settembre 2002, A. C. Quintavalle (ed.), Parma-Milán, 2005, pp. 211-226.

56 M. CAstiÑEIRAs, "La catedral de Santiago", "Didacus Gelmirius". 
1124. Entre esas dos fechas, Compostela pudo desarrollar un programa figurativo perfectamente vanguardista, que sintetizaba la experiencia del arte de los Caminos de Peregrinación con la emergencia del arte de la Reforma Gregoriana en Italia. Sus hitos son los siguientes: elevación de las fachadas del transepto entre 1101 y 1111 , y consagración del altar mayor y capillas de la cabecera, entre 1105 y 1106. Unas serie de fechas parecen corroborarlo: el inicio del nuevo palacio en la platea de Platerías en 1101; la inscripción de la jamba izquierda de la entrada oriental de Platerías, realizada en 1103; la inscripción conmemorativa de la consagración de la Capilla del Salvador y el epígrafe del frontal de plata, colocado en el quinto año del pontificado de Gelmírez; el enterramiento del Conde de Galicia, Raimundo de Borgoña, en la Porta Francigena en 1107; la inscripción laudatoria al rey de Galicia, Alfonso Raimúndez, en el friso de Platerías, con motivo de su coronación en el altar mayor jacobeo en 1111; y la definitiva destrucción del perímetro de la basílica de Alfonso III en $1112^{57}$. Por el contrario, la fecha de 1122 de la fuente del Paradisus señalaba la finalización de tribunas, cubiertas y espacios públicos en el entorno de la catedral.

\section{Maestros y modelos prestigiosos: entre deuda y originalidad}

La erección de la Porta Francigena y de Platerías necesitaba de la participación de artesanos hábiles en el manejo del cincel, que, a mi entender, fueron contratados durante el primer viaje de Gelmírez o como directa consecuencia del mismo. Hacia 1101, un año después del primer itinerario a Roma, tras la consagración episcopal del 21 de abril de 1101 y el consiguiente inicio de las obras del nuevo palacio episcopal en la platea sur, tuvieron que iniciar sus trabajos los cinco maestros activos en las portadas: el Maestro de la Porta Francigena, el Maestro de las Columnas Entorchadas, el Maestro del Cordero, el Maestro de las Tentaciones (o de Conques) y el Maestro de la Traición. Mientras que cuatro se dedican fundamentalmente a la portada norte -Francigena, Columnas Entorchadas, Cordero y Traición-, el de las Tentaciones se consagra exclusivamente desde el primer momento a la puerta sur. No obstante, un cambio de proyecto en Platerías hace que hacia 1103 el maestro de la Porta Francigena y el de la Traición incorporen sus relieves a dicha fachada sur. En mi opinión, hacia 1105, los Maestros de las Tentaciones y de la Traición aprovecharon el segundo viaje de Gelmírez para volver a Conques e incorporarse de nuevo al taller del abad Bégon III, de donde habían salido años antes camino de Compostela ${ }^{58}$. En Platerías trabajaría también un sexto maestro, el Maestro de la Transfiguración, que no trataremos aquí.

\footnotetext{
57 Para nuevas lecturas sobre los epígrafes de la Capilla del Salvador, del frontal de plata del altar mayor y de las jambas de Platerías, véase mi trabajo: "Las portadas del crucero de la Catedral de Santiago (11011111)", pp. 75-76.

58 M. CAstiñeIRAs, "Da Conques a Compostella: retorica e performance nell'era dei portali parlanti", Medievo: Immagine e Memoria, Atti del XI Convegno Internazionale di Studi, Parma, 23-28 settembre 2008, A. C. Quintavalle (ed.), Milán-Parma, 2009, pp. 233-251.
} 
Como ya se ha señalado, el presente trabajo se centrará en el análisis de los maestros activos en la Porta Francigena ${ }^{59}$. El primero y más genial, que denominamos propiamente el Maestro de la Porta Francigena fue el que en su día Moralejo llamó "de Platerías" y al que la vieja historiografía quiso identificar, de forma totalmente errónea, con el Maestro Esteban. Su nuevo nombre hace así justicia a la obra para la que esculpió sus más célebres relieves: la Porta Francigena. Dicho escultor es, sin duda alguna, con sus peculiares figuras de rostros de carrillos hinchados, vigorosa anatomía y contrastado modelado de paños (Creación de Adán, David (fig. 17), Mujer del León, Mujer de las Uvas, Hombre que cabalga el gallo, etc.) un heredero del gusto por la Antigüedad del Maestro de Jaca que debió conocer directamente $-\mathrm{O}$ incluso formarse- en la extraordinaria experiencia monumental del taller de la Porte Miègeville de Saint-Sernin de Toulouse, en cuyos relieves ya se trabajaba posiblemente hacia 1100 (fig 18), tal y como sugieren las recientes investigaciones de Daniel y Quitterie Cazes ${ }^{60}$. Muy posiblemente es gracias al viaje que Gelmírez realiza a Roma en 1100 , acompañado por miembros de su curia, para ser ordenado subdiácono, a través de la vía tolosana, que

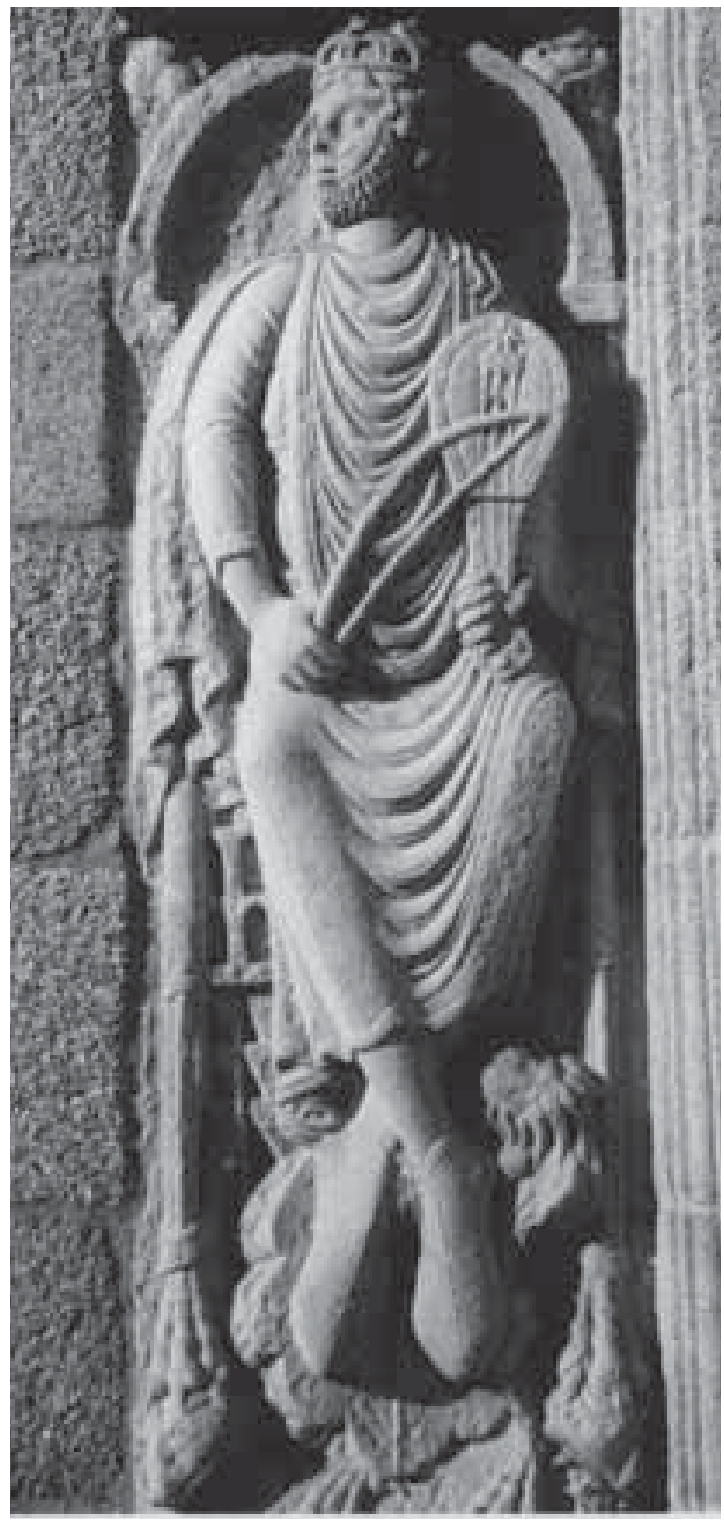

Fig. 17. Catedral de Santiago, fachada sur (Platerías), contrafuerte izquierdo: Maestro de la Porta Francigena, David, 1101-1111. Relieve procedente de la Porta Francigena.

59 En la definición de todos estos "maestros" se parte de trabajos de Moralejo de 1969 ("La primitiva puerta norte"), incorporando aportaciones y matices importantes desarrollados por mí en los últimos años.

60 D. y Q. CAZEs, Saint-Sernin de Toulouse. De Saturnin au chef d'oeuvre de l'art roman, Toulouse, 2008. 


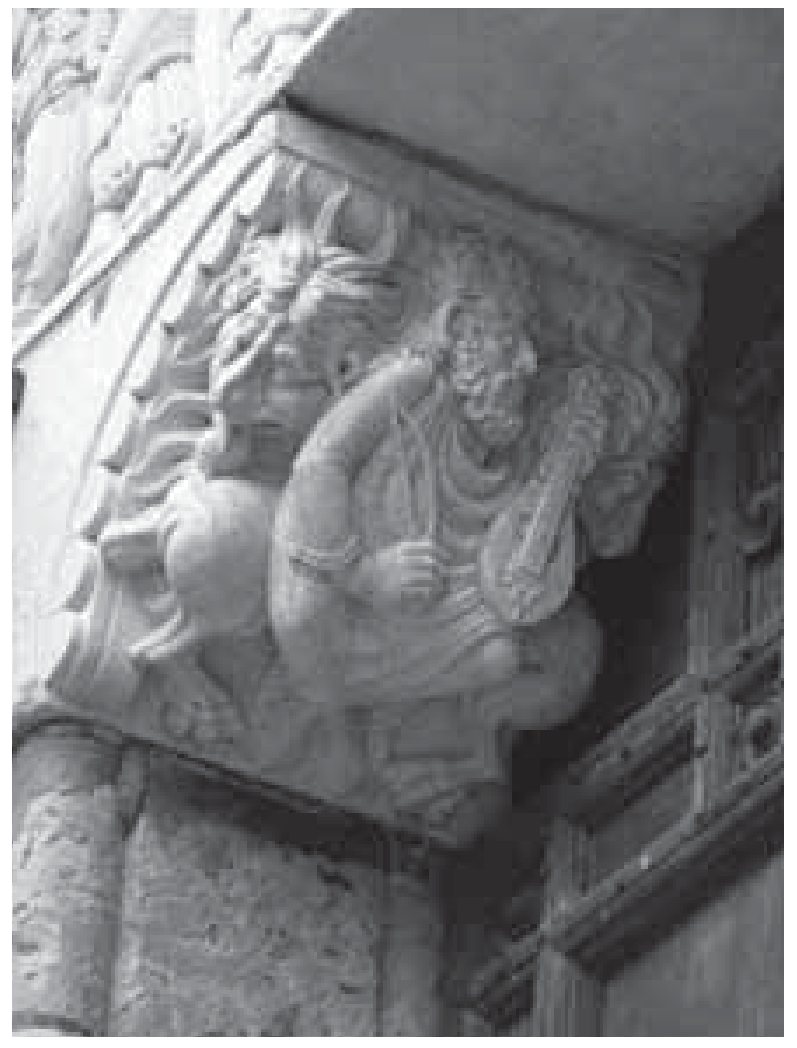

Fig. 18. Saint-Sernin de Toulouse, Porte Miègeville, mocheta derecha: David, ca. 1100-1105.

dicho maestro foráneo se incorporó al nuevo obrador compostelano. El segundo maestro, responsable de las magníficas columnas entorchadas -Maestro de las Columnas Entorchadas, al que F. Prado-Vilar denomina Maestro de Ulises ${ }^{61}$ estaba formado igualmente en la tradición jaquesa, pero se caracteriza por permanecer más fiel al clasicismo que distinguía a este taller y enriquecerlo con las novedades de la experiencia romana contemporánea, como veremos más adelante. A ellos hay que añadir el denominado Maestro de la Puerta del Cordero, de volúmenes geométricos, de superficie pulimentada, rostros intemporales, ojos abultados y tendencia a la frontalidad, (Pantocrator del contrafuerte izquierdo de Platerías, Signo de Mateo, Creación de Eva). Se trata de un escultor local, formado seguramente en León y, por lo tanto, conocedor la tradición jaquesa, influido en Compostela por el Maestro de la Porta Francígena, pero menos dotado para articular un lenguaje artístico monumental sofisticado. Por último, en la Puerta Francígena, trabaja también un cuarto artista, de formación muy distinta a los tres precedentes: el Maestro de la Traición. Se trata de un seguidor del Maestro de las Tentaciones, y como él procedente del Conques del abad Bégon, que domina la narración y utiliza figuras en tres cuartos, de rostros ingenuos, pupilas excavadas rellenas de pasta vítrea, grandes bigotes, pliegues gruesos que se ciñen a la parte inferior del cuerpo y marcada tendencia al bulto (Reprensión y Expulsión de Adán y Eva).

De manera extraordinaria para esas fechas, los relieves salidos de la mano de los diferentes escultores cubrieron, como en la fachada sur-Platerías-, la totalidad de la superficie de la fachada norte. Su primitiva ubicación en la misma se conoce

61 F. Prado-Vilar, "Nostos, Ulises, Compostela y la ineluctable modalidad de lo visible", Compostela y Europa. La historia de Diego Gelmírez, pp. 260-269. 
gracias a la descripción de la Guía del Calixtino (V, 9): jambas con Apóstoles, mochetas con cabezas de buey, enjutas extremas con leones, tímpano del ingreso izquierdo con la Anunciación, así como un frontispicio profusamente decorado. En él se incluían, directamente sobre los arcos de las puertas, sendos frisos de pequeñas lastras con relieves profanos consistentes en un ciclo con los Meses del Año (izquierda) y personificaciones del pecado, compuestas por el Centauro, la Sirena, el Ballestero y el Hombre que cabalga un gallo. Estos últimos cuatro relieves, de formato cuadrangular similar, en origen formaban parte de la serie de las imágenes de "bestias, de hombres, de ángeles, de mujeres, de flores y de otras criaturas" (Guía del Calixtino V, 9) que decoraban el primitivo portal y que fueron en el siglo XVIII reaprovechados en Platerías. Aunque desconocemos exactamente la localización exacta de estos últimos relieves dentro de la fachada primitiva algunos indicios, y el posible eco de su estructura en la fachada norte de San Quirce de Burgos ${ }^{62}$, llevan a pensar en su colocación en friso sobre la puerta derecha en perfecta simetría con el de los Meses situado sobre la puerta izquierda.

Otro monumento sugerente, con respecto a la Porta Francigena, es la Puerta del Cordero de San Isidoro de León, cuyo frontispicio, sin embargo, fue alterado en época moderna para colocar la actual peineta que lo corona (fig. 19). De hecho, el célebre friso del Zodiaco estaba acompañado, probablemente en la parte superior, de una serie de tituli que corroboran su lectura de derecha a izquierda: "GEMINI: TAU/RUS: ARIES" ${ }^{63}$. Aunque hace años propuse que signos e inscripciones conformaban, en origen, un friso de canes y metopas un análisis detenido de las piezas me hace descartar esa posibilidad: los signos zodiacales, en su actual disposición, presentan una anchura irregular, más estrechos en la parte central -Cáncer y Virgo-, que sugieren su concepción primigenia como friso corrido sobre una puerta, tal cual todavía están hoy. Su similitud con el destruido calendario de la Francigena resulta obvia, si bien en Compostela se invierten los términos con respecto a León: el gran despliegue narrativo está sobre el friso de los meses, mientras que en el caso leonés se sitúa debajo del friso en la representación de David y sus músicos. Para valorar los intercambios entre ambos conjuntos habría primero que resolver la cuestión de la datación controvertida de la Puerta del Cordero. Para Therese Martin, Marta Poza y Francisco Prado-Vilar ${ }^{64}$ se trataría, utilizando distintos argumentos, de un con-

${ }^{62}$ M. CastiñEIRAs, "Didacus Gelmirius, patrono de las artes", p. 65-67. Sobre el conjunto de San Quirce de Burgos, véase el sugerente estudio de D. Rico CAmps, Las voces del Románico. Arte y epigrafía en San Quirce de Burgos, Murcia, 2008, esp. 89.

${ }^{63}$ Sobre la localización actual de estos epígrafes, véase: T. MArTin, Queen as King. Politics and Architectural Propaganda in Twelfth-Century Spain, Leiden-Boston, 2006, p. 92, fig. 39ab. Para un estudio de la iconografía del zodiaco leonés, véase: S. Moralejo, "Pour l'interprétation iconographique du Portail de l'Agneau à Saint-Isidore de León: les signes du zodiaque”, Les Cahiers de Saint-Michel de Cuxa, 8, 1977, pp. 137-173.

${ }_{64}$ T. MARTin, Queen as King, 92; M. POZA YAGÜE, "Entre la tradición y la reforma. A vueltas de nuevo con las portadas de San Isidoro de León”, Anuario del Departamento de Historia y Teoría del Arte, XV, 2003, p. 9-27; F. Prado-VILAR, “Lacrimae rerum: san Isidoro de León y la memoria del padre”, Goya, 328, 2009, p 195-221, esp. p. 218 , n. 41 y 43 


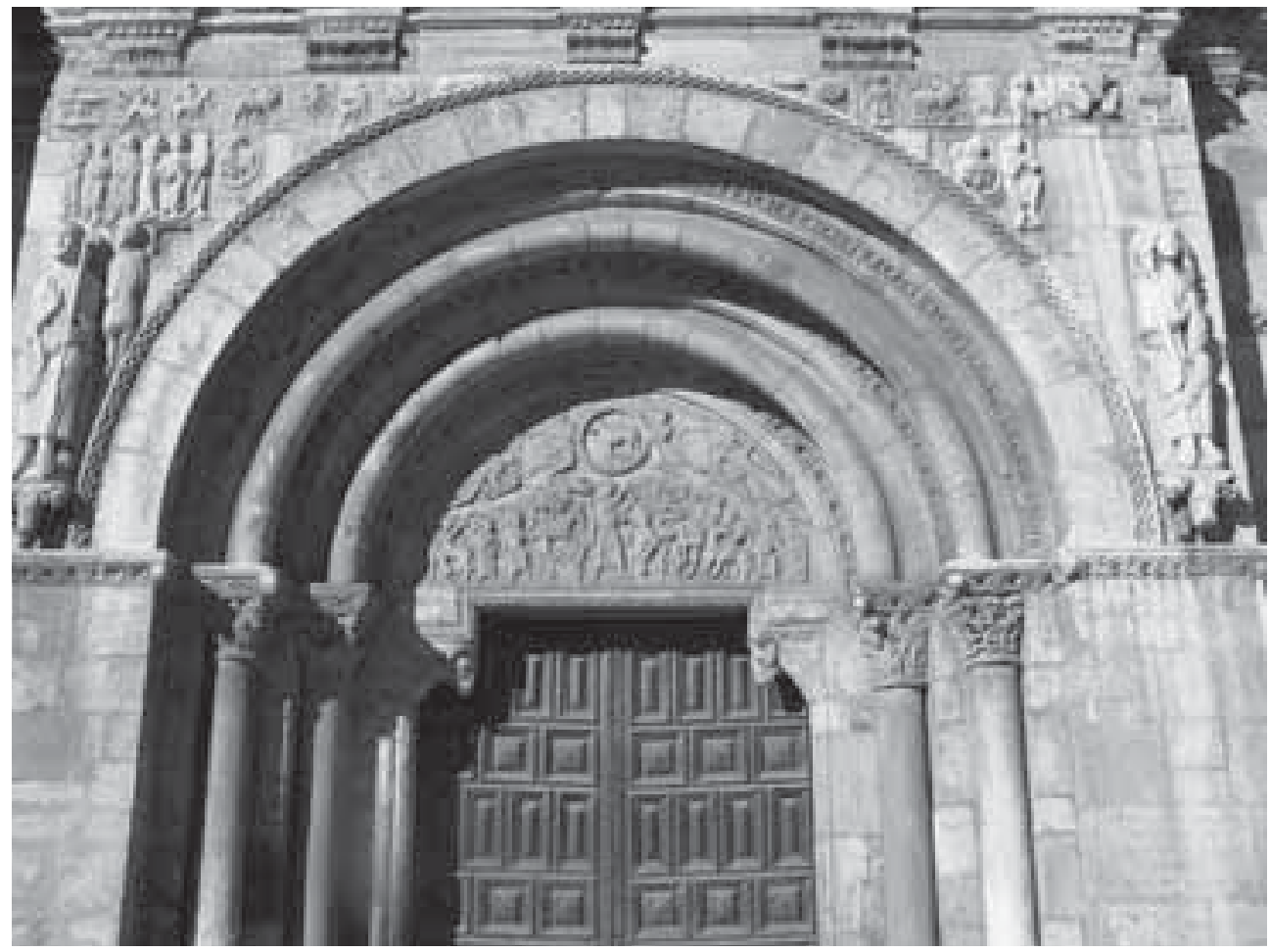

Fig. 19. San Isidoro de León, lado sur, Puerta del Cordero, ca. 1101.

junto realizado bajo el mecenazgo de la infanta Urraca de Zamora, patrona de San Isidoro, entre la década de 1090 y el año de su fallecimiento, 1101, mientras que Gerardo Boto, a partir del análisis de la fases constructivas del edificio, propone que la portada estaría realizada antes del año 1110 , si bien reconoce que ya se debía estar trabajando en la fachada en $1101^{65}$. En mi opinión, siguiendo, en particular, la sólida hipótesis de Francisco Prado-Vilar ${ }^{66}$, existen suficientes argumentos para pensar que en la concepción del citado portal leonés se gestaron algunas de las soluciones de la francigena, como la tipología de friso sobre puerta o el carácter artístico del denominado "Maestro del Cordero" activo en la Porta Francigena, deudor epigonal del estilo de las lastras mayores de las enjutas del citado portal leonés.

Volviendo a lo que la portada norte de San Quirce de Burgos pudiera tener de eco de las portadas del transepto compostelano, me gustaría llamar la atención sobre una serie de cuestiones. En primer lugar, desde un punto de vista tipológico, la

${ }^{65}$ G. Boto Varela., Arquitectura Medieval. Configuración espacial y aptitudes funcionales, San Isidoro de León. Relicario de la monarquía leonesa, C. Robles, F. Llamazares (ed.), León, 2007, pp. 52-103.

${ }_{66}$ F. PRADO-VILAR, Lacrimae rerum, p. 218, n. 41 y 43. Agradezco a Francisco Prado-Vilar sus útiles y atinadas indicaciones sobre la cronología de la Puerta del Cordero. 
portada burgalesa presenta un frontispicio totalmente cubierto de relieves cuadrangulares y rectangulares, como sucedía en las fachadas compostelanas, y se enmarca con un animado alero de canes figurados, como el que seguramente existía en la primitiva francigena o el que todavía puede contemplarse en Platerías. Por otra parte, en lo que se refiere su iconografía, en San Quirce se repiten muchos temas de las portadas compostelanas: así el Cristo en Majestad rodeado de un Tetramorfos y la Anunciación del frontispicio burgalés se situaban, en la Porta Francigena, respectivamente, en el centro y en uno de los tímpanos, mientras que el apostolado que decora el alero se encontraba en Platerías en el frontispicio.

Todas las piezas del repertorio profano de la primitiva Puerta Norte de Santiago -Centauro, la Sirena, el Ballestero y el Hombre que cabalga un gallo-, son atribuibles al Maestro de la Porta Francigena y aluden a las consecuencias derivadas del Pecado Original, cuya historia se exponía en el friso superior contiguo. La música de la voz de la Sirena representaba desde La Odisea el encantamiento de la destructora seducción femenina, imagen ahora del engaño y el embrujo de los placeres del mundo. Por ello la figura es herida por las flechas del Centauro, representado así una alegoría de la lucha contra el mal. Por su parte, el Hombre cabalgando un gallo constituía por antonomasia la imagen de la lujuria masculina. De esta forma, las lastras funcionarían como metafóricas referencias a la codicia y lubricidad de Adán y Eva y al poder seductor del demonio. Por último, el Ballestero, imagen de la discordia, amplifica los efectos del Pecado Original, ya que no hay que olvidar que la ballesta era no sólo odiada entonces por su potencia mortífera sino que era considerada un arma diabólica, llegando incluso a ser condenado su uso en el II Concilio Lateranense ${ }^{67}$.

El frontispicio estaba presidido, justo sobre ambos ciclos profanos, por un gran friso historiado de temática bíblica compuesto por multitud de piezas que narraba la historia de la Creación y Caída de Adán y Eva, siguiendo los modelos ilustrativos de las biblias carolingias. En el centro de este programa se situaba la figura del Pantocrátor con los cuatro símbolos de los Evangelistas. Muy posiblemente a ambos lados de este gran ciclo bíblico se disponían lastras, igualmente de formato rectangular, relativas a la promesa de redención-David músico vence al demonio, Sacrificio de Isaac, Mujer del león, Mujer de las uvas-. El misterioso contenido de estas dos immagines feminarum, a las que se refiere el Códice Calixtino (V, 9) hay que interpretarlo, tal y como señaló en su día S. Moralejo, en clave cristológica, como imagen alegórica de las dos naturalezas, divina y humana, de Cristo: león vencedor pero también víctima de sacrificio. En conclusión, si la asociación monumental entre un ciclo del Génesis y de los Meses ofrecía la posibilidad de la redención del pecado a través del trabajo, la esperanza en la próxima venida del

${ }^{67}$ M. CASTIÑEIRAS, "A poética das marxes no románico galego: bestiario, fábulas e mundo ó revés", Profano y pagano en el arte gallego, M. Castiñeiras y F. Díez Platas (eds.) Santiago, 2003, pp. 293-334, esp. p. 310 (Semata, 12, 2002). 
Mesías se expresaba a través de su prefiguración en David e Isaac, así como en los atributos femeninos del León de Judá y de la Vid del sacrificio eucarístico. Por último, el contenido de este mensaje de redención se hacía explícito en el relieve de la Anunciación del tímpano.

Como si se tratase de un gran decorado, el programa iconográfico de la primitiva Puerta Norte participaba plenamente del carácter funcional y simbólico del espacio urbano que definía. La plaza, denominada Paradisus, no sólo era una emulación del Paraíso del antiguo San Pedro de Roma, sino que además intentaba evocar el aspecto del Edén bíblico. Dicho locus amoenus se significaba a través de una fuente -la fons vitae-coronada por cuatro leones, de cuyos caños manaba el agua a la manera de los Ríos del Paraíso (figs. 2-3), así como por el empleo en el frontispicio de la fachada de hermosas lastras con decoración vegetal junto a relieves historiados con el ciclo de la Caída de Adán y Eva. Por esta razón, Serafín Moralejo no dudó en proponer que el programa iconográfico de la fachada y su entorno urbano constituían el marco adecuado para la celebración de los ritos penitenciales del Miércoles de Ceniza y su posterior reconciliación durante la Semana Santa ${ }^{68}$.

\section{Tras las huellas de la conexión romana: las columnas entorchadas}

No es mi intención volver a exponer aquí, una vez más, mi hipótesis sobre las columnas entorchadas de la desaparecida puerta norte ${ }^{69}$ sino señalar sus posibles vías de estudio. Con gran acierto, S. Moralejo había visto en ellas una evocación de la célebre pérgola apostólica en el altar mayor de San Pedro de Roma, con fustes helicoidales decorados con putti vendimiadores ${ }^{70}$. No obstante, un estudio detenido de los motivos de los fustes compostelanos con esta temática me han llevado desde hace años a señalar su similitud con las interpretaciones contemporáneas de las columnas de San Pedro realizadas a fines del siglo XI por los marmolistas romanos, como las conservadas en Santa Trinità dei Monti (Roma) y en San Carlo a Cave (Lacio) (ca. 1093) $)^{71}$, y no tanto al modelo vaticano. De hecho,

68 S. Moralejo, "La imagen arquitectónica de la Catedral de Santiago", Il Pellegrinaggio a Santiago de Compostela e la letteratura jacopea . Atti del Convegno Internazionale di Studi, Perugia, 1983, Perugia, 1985 , pp. 37-61.

${ }^{69}$ El tema ha sido tratado por mí en trabajos precedentes: "Roma e il programma riformatori di Gelmírez", "La catedral de Santiago de Compostela", "Didacus Gelmirius, patrón de las artes".

70 S. Moralejo, "Saint-Jacques de Compostelle. Les Portails retrouvés de la cathédrale romane", Les dossiers de l'archeologie, 20 (1977), pp. 87-103; "La imagen arquitectónica de la Catedral de Santiago", "El patronazgo artístico del arzobispo Diego Gelmírez".

71 Para la datación de las columnas salomónicas romanas, véase: P. C. Claussen, "Römische Slulptur aus der zweiten Hälfte des 11. Jahrhunderts", Patrimonio artístico de Galicia y otros estudios. Homenaje al Prof. Dr. Serafin Moralejo Álvarez, vol. 3, Santiago de Compostela, 2004, pp. 71-80, Idem, "Un nuevo campo della storia dell'arte. Il secolo XI a Roma”, Roma e la Riforma gregoriana. Tradizione e innovazione artistiche (XIXII secolo), Roma, 2007, pp. 61-71. Para una estado de la cuestión del estudio de dichas columnas, véase: V. NodAr, "Colonne salomoniche della chiesa della Santissima Trinità dei Monti a Roma e di San Carlo a Cave", 
tal y como hemos señalado, las columnas compostelanas fueron realizadas probablemente poco después de 1100, tras el primer viaje de Gelmírez a Roma para recibir delante de la pérgola de San Pedro del Vaticano la dignidad de subdiácono. Con toda probabilidad, el séquito de Gelmírez tuvo acceso en sus visitas a la Ciudad Eterna a un modelo o cartón que circulaba desde fines del siglo XI en los talleres de los marmolistas romanos. De hecho, es evidente la similitud entre los esquemas compositivos y ornamentales de las columnas medievales romanas y los fustes compostelanos. Éste es el caso, por ejemplo, del amorcillo vendimiador junto a un ave, de los putti que comen de un racimo, de las alimañas que muerden la viña o de las aves que la pican las uvas.

Evidentemente la factura y ejecución de las columnas romanas y compostelanas es muy diversa, puesto que el estilo del Maestro de las Columnas Entorchadas tiene mucho que ver con la tradición volumétrica jaquesa, marcada por la organicidad y la vocación relivaria, frente al schiacciato o aplanamiento de los marmolistas de Trinità y Cave. No obstante, en ambos casos se trata de claras derivaciones de estilos antiguos, presentes en sarcófagos de los siglos II y III d.C.. El Maestro de las Columnas Entorchadas enriqueció su repertorio gracias al conocimiento directo de estas interpretaciones medievales de las columnas de la pérgola de San Pedro, que, buscaban subrayar en la elección y reiteración de motivos un significado eclesiológico acorde con los ideales de la Iglesia Romana de fines del siglo XI, de clara oposición entre el bien (los vendimiadores) y el mal (alimañas, aves, serpientes, lagartijas). Ese combate llega a ser ejemplificado perfectamente en Trinità dei Monti a través de un vendimiador que lleva en su hombro grabada la Cruz de Cristo (fig. 20).

No cabe duda alguna que este mensaje se entiende perfectamente en Santiago, pues en el Liber sancti Iacobi (I, 6), en el Sermón de la Pasión del Apóstol (25 de julio), se habla de las barbarae ferae y de las vulpes hereticae -que pululan en las columnas de Cave, Trinità dei Monti y Santiago-, como enemigos del apostólico vendimiador de la Viña de la Iglesia. Otro tanto se puede afirmar de la representación de los pájaros de otro de los fustes compostelanos que como en los ejemplares romanos pican con maldad la viña. No obstante, en el caso de Compostela en uno de las columnas un amorcillo atrapa con fuerza una paloma por el cuello para proteger su afanoso trabajo (fig. 21) en directa correspondencia con el contenido de los versos de un himno de san Fortunato recogido en el mismo sermón del Calixtino:

La uva hinchada en el pámpano, que pasto

sería de los pájaros, con este

guardián el buen lagar no ha de perderla ${ }^{72}$.

Compostela y Europa. La historia de Diego Gelmírez, M. CAStiÑEIrAs (ed.), Milán, 2010, fichas cat. nº 19-20, pp.346-348.

${ }^{72}$ CC, I, 6, trad. cit. p. 41. 
La primitiva Porta Francigena parecía adherirse así, de manera muy directa y particular, al ideario del arte de la Reforma Gregoriana haciendo una cita explícita a la Roma Papal. Es esa voluntad estético-ideológica, propia de una sede pretendidamente apostólica, la que permite destacar la primitiva puerta compostelana de otros monumentos escultóricos emergentes entonces fuera de Roma, que también se sumaban entonces al ideario reformista, como la Porta Miègeville o la fachada occidental de la Catedral de Módena.

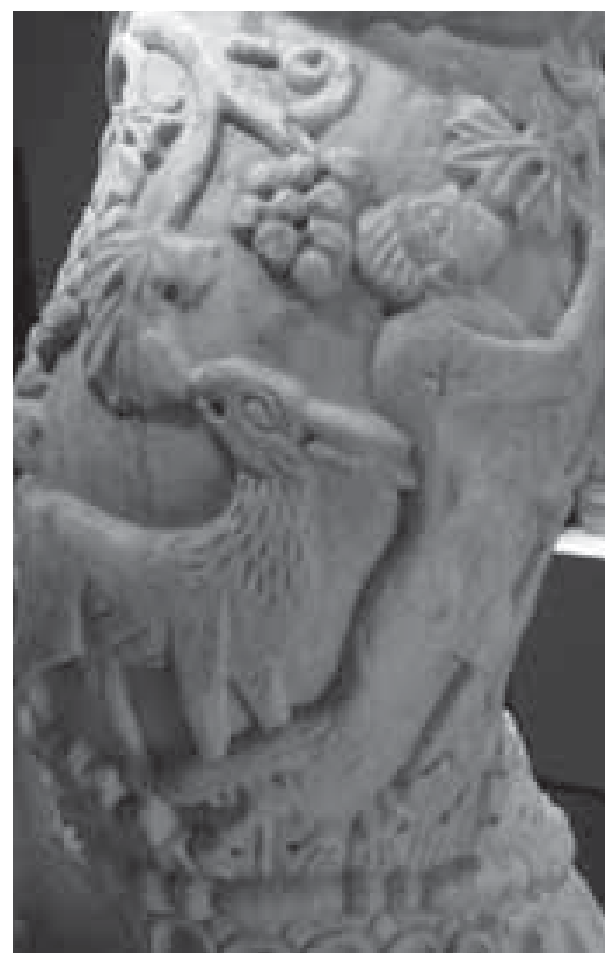

Fig. 20. Santissima Trinità dei Monti, columna salomónica, ca. 1090-1100.

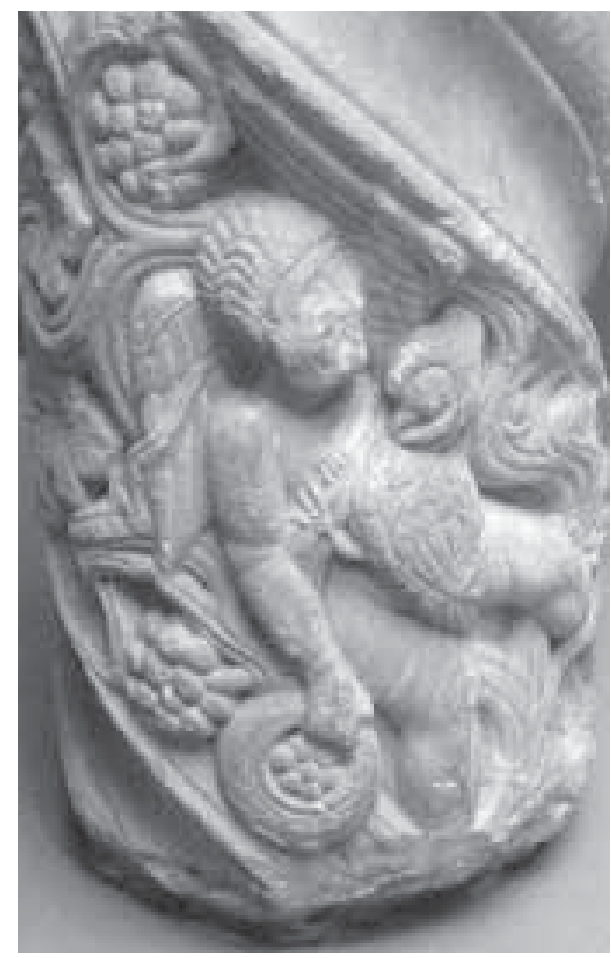

Fig. 21. Maestro de las Columnas Entorchadas: fragmento de fuste entorchado procedente de la primitiva Porta Francígena: 1101-1111. Museo da Catedral de Santiago. 